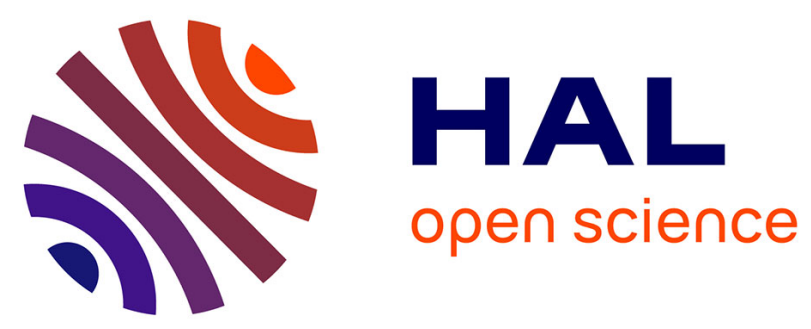

\title{
Concomitant downregulation of proliferation/survival pathways dependent on FGF-R3, JAK2 and BCMA in human multiple myeloma cells by multi-kinase targeting
}

Giuliana Cassinelli, Domenica Ronchetti, Diletta Laccabue, Michela Mattioli, Giuditta Cuccuru, Enrica Favini, Valentina Nicolini, Angela Greco, Antonino Neri, Franco Zunino, et al.

\section{To cite this version:}

Giuliana Cassinelli, Domenica Ronchetti, Diletta Laccabue, Michela Mattioli, Giuditta Cuccuru, et al. Concomitant downregulation of proliferation/survival pathways dependent on FGF-R3, JAK2 and BCMA in human multiple myeloma cells by multi-kinase targeting. Biochemical Pharmacology, 2009, 78 (9), pp.1139. 10.1016/j.bcp.2009.06.023 . hal-00519079

\section{HAL Id: hal-00519079 \\ https://hal.science/hal-00519079}

Submitted on 18 Sep 2010

HAL is a multi-disciplinary open access archive for the deposit and dissemination of scientific research documents, whether they are published or not. The documents may come from teaching and research institutions in France or abroad, or from public or private research centers.
L'archive ouverte pluridisciplinaire HAL, est destinée au dépôt et à la diffusion de documents scientifiques de niveau recherche, publiés ou non, émanant des établissements d'enseignement et de recherche français ou étrangers, des laboratoires publics ou privés. 


\section{Accepted Manuscript}

Title: Concomitant downregulation of proliferation/survival pathways dependent on FGF-R3, JAK2 and BCMA in human multiple myeloma cells by multi-kinase targeting

Authors: Giuliana Cassinelli, Domenica Ronchetti, Diletta Laccabue, Michela Mattioli, Giuditta Cuccuru, Enrica Favini, Valentina Nicolini, Angela Greco, Antonino Neri, Franco

Zunino, Cinzia Lanzi

PII: S0006-2952(09)00492-4

DOI: doi:10.1016/j.bcp.2009.06.023

Reference: BCP 10232

To appear in: $B C P$

Received date: 25-3-2009

Revised date: 28-5-2009

Accepted date: $16-6-2009$

Please cite this article as: Cassinelli G, Ronchetti D, Laccabue D, Mattioli M, Cuccuru G, Favini E, Nicolini V, Greco A, Neri A, Zunino F, Lanzi C, Concomitant downregulation of proliferation/survival pathways dependent on FGF-R3, JAK2 and BCMA in human multiple myeloma cells by multi-kinase targeting, Biochemical Pharmacology (2008), doi:10.1016/j.bcp.2009.06.023

This is a PDF file of an unedited manuscript that has been accepted for publication. As a service to our customers we are providing this early version of the manuscript. The manuscript will undergo copyediting, typesetting, and review of the resulting proof before it is published in its final form. Please note that during the production process errors may be discovered which could affect the content, and all legal disclaimers that apply to the journal pertain. 


\section{Concomitant downregulation of proliferation/survival pathways dependent on FGF-R3, JAK2 and BCMA in human multiple myeloma cells by multi-kinase targeting}

Giuliana Cassinelli ${ }^{1}$, Domenica Ronchetti ${ }^{2}$, Diletta Laccabue ${ }^{1}$, Michela Mattioli ${ }^{2}$, Giuditta Cuccuru $^{1}$, Enrica Favini ${ }^{1}$, Valentina Nicolini ${ }^{1}$, Angela Greco ${ }^{1}$, Antonino Neri ${ }^{2}$, Franco Zunino ${ }^{1}$ and Cinzia Lanzi ${ }^{1}$

${ }^{I}$ Dipartimento di Oncologia Sperimentale e Medicina Molecolare, Fondazione IRCCS Istituto Nazionale dei Tumori, ${ }^{2}$ Dipartimento di Scienze Mediche, Università di Milano, Ematologia 1CTMO, Fondazione IRCCS Policlinico MaRe; ${ }^{3}$ Dipartimento di Scienze Biomediche e Tecnologie, Università di Milano, Milano, Italy.

Category: Antibiotics and Chemotherapeutics

Correspondence: Cinzia Lanzi,

Chemotherapy and Pharmacology Unit

Dipartimento di Oncologia Sperimentale e Laboratori

Fondazione IRCCS Istituto Nazionale dei Tumori, via Venezian 1, 20133

Milan, Italy

Phone: 39-02-23902627;

Fax: 39-02-23902692;

E-mail: cinzia.lanzi@,istitutotumori.mi.it 
Abbreviations: $\quad$ aFGF, acidic fibroblast growth factor

BCMA, B-cell maturation antigen

$\mathrm{BM}$, bone marrow

GEP, gene expression profile

HMCL, human multiple myeloma cell lines

MM, multiple myeloma

MSC, mesenchymal stromal cell 


\begin{abstract}
The identification of proliferation/survival pathways constitutively activated by genetic alterations in multiple myeloma $(\mathrm{MM})$, or sustained by the bone marrow (BM) microenvironment, provides novel opportunities for the development of targeted therapies. The deregulated function of protein tyrosine kinases plays a critical role in driving MM malignant phenotype. We investigated the effects of the multi-target tyrosine kinase inhibitor RPI-1 in a panel of human MM cell lines, including $\mathrm{t}(4 ; 14)$ positive cell lines expressing the TK receptor FGF-R3. Cells harboring FGF-R3 activating mutations (KMS11 and OPM2) displayed the highest sensitivity to RPI-1 antiproliferative effect. The stimulating effect of the aFGF ligand was abrogated in cells harboring a non-constitutively active receptor. Drug treatment inhibited activation and expression of the FGF-R $3^{\mathrm{Y} 373 \mathrm{C}}$ mutant as well as aFGF-dependent signaling involving AKT and ERKs. Inhibition of JAK2, an additional RPI-1 target, resulted in STAT3 inactivation. Blockade of these proliferation/survival pathways was associated with caspasedependent apoptosis. Moreover, drug treatment abrogated proliferative and pro-invasive stimuli provided by conditioned medium from mesenchymal stromal cells. Gene expression profile of KMS11 cells showed 22 upregulated and 52 downregulated genes upon RPI-1 treatment, with an early modulation of genes implicated in MM pathobiology such as $S A T-1, M Y C, M I P-1 \alpha / \beta, F G F$ $R 3$, and the growth factor receptor B-cell maturation antigen (BCMA). Thus, concomitant blockade of FGF-R3 and JAK2 results in inhibition of several MM-promoting pathways, including BCMA-regulated signaling, and downregulation of disease-associated proteins. These data may have therapeutic implications in the design of treatment strategies resulting in the concomitant inhibition of FGF-R3 and JAK2 signaling pathways in t(4;14) MM.
\end{abstract}

Key words: BCMA; FGFR3; JAK2; Multiple Myeloma; RPI-1 


\section{Introduction}

Multiple myeloma (MM), which is regarded as an incurable neoplasia, is characterized by clonal expansion of a monotypic plasma cell population in the bone marrow (BM) and induction of osteolytic bone lesions [1]. MM plasma cells harbor chromosome abnormalities most frequently represented by chromosomal translocations involving the IgH locus at chromosome 14 (14q32), which result in the dysregulation of a variety of oncogenes and are significantly associated with shorter survival [2]. The $\mathrm{t}(4 ; 14)$ translocation described in $20 \%$ of MM patients results in ectopic expression of the fibroblast growth factor receptor 3 (FGF-R3) and enhanced expression of MMSET, a gene involved in transcription regulation [3-5]. FGF-R3, a member of the FGF receptor tyrosine kinase family, has also been found mutated in about $6 \%$ of tumors with $\mathrm{t}(4 ; 14)$ $[1,6]$. Although the pathogenic role of $F G F-R 3$ overexpression in $\mathrm{MM}$ has not been clearly defined, the acquisition of kinase-activating mutations appears to confirm its role in the multistage disease process $[5,7]$.

In addition to the tumor genetic background, the BM microenvironment is well recognized as a crucial determinant of the biological and clinical behavior of MM [8]. Extracellular matrix components, stromal cells and secreted growth factors support the malignant growth of MM cells in the BM milieu. The best characterized myeloma growth factor is the cytokine interleukin-6 (IL-6) [9]. However, an increasing number of cytokines, chemokines and cell-to-cell contacts provided by the BM has been found to activate a pleiotropic cascade of proliferative/antiapoptotic signaling pathways including JAK/STAT, PI3K/AKT, RAS/ERK and their downstream components [10]. A better understanding of the profile of signaling pathways involved in the pathophysiology of the disease now provides a framework for the identification of novel targets [1,11]. Accordingly, novel agents recently approved in clinical protocols for MM, 
such as bortezomib, thalidomide and analogs, share the ability of targeting tumormicroenvironment interactions as an essential part of their mechanism of action $[8,12]$.

The complex signaling network activated by oncogenic mutations and by the BM microenvironment sustains growth, survival and migration of MM cells contributing to tumor progression as well as to resistance to conventional chemotherapy $[1,8]$. Since failure to undergo apoptosis has been suggested to play a main role in MM cell accumulation within the BM as well as in drug resistance [9], blocking both intrinsic and BM microenvironment-driven signaling could be required to induce tumor cell death. Multi-targeting approaches represent thereby an attractive therapeutic strategy for MM.

Simultaneous inhibition by small molecule inhibitors of protein tyrosine kinases oncogenically activated in $\mathrm{MM}$ cells, and/or regulated by the $\mathrm{BM}$ microenvironment, is an attractive therapeutic approach. The 2-indolinone compound RPI-1 was previously described as a multi-target tyrosine kinase inhibitor showing antitumor and antimetastatic/antiangiogenic activity against human tumor models harboring oncogenic RET or overexpressing c-MET [1318]. In the present study, the effects of the drug were investigated in a panel of human MM cell lines (HMCLs). FGF-R3 and JAK2 were identified as RPI-1 targets mediating antimyeloma activity in vitro. Moreover, expression analysis of drug-treated cells showed the modulation of several key disease-associated genes and proteins including the growth factor receptor B-cellmaturation antigen (BCMA).

\section{Materials and Methods}

\subsection{Cell lines and culture conditions}

HMCLs (see Table 1) were obtained from DMSZ-German collection of Microorganisms and Cell Culture, Germany (OPM2, JJN3), or kindly provided by Dr. T. Otsuki (Kawasaki Medical 
School, Okayama, Japan) (KMS-28, KMS-18, KMS-11, and KMS-20). They were maintained routinely in Iscove's Modified Dulbecco's Medium supplemented with 10\% fetal bovine serum. Multipotent human mesenchymal stromal cells (MSCs) from normal BM adherent cells were kindly provided by Dr. M. Introna (Ospedali Riuniti, Bergamo, Italy) and cultured in Dulbecco's modified Eagle medium, low glucose, with $10 \%$ fetal bovine serum. Conditioned medium from MSCs was harvested after $48 \mathrm{~h}$ of culture in complete medium. The murine fibroblast cell lines NIH3T3 and A6-KMS11 (NIH3T3 stably transfected with the FGF-R3 mutant Y373C) (7) were cultivated in Dulbecco's Modified Eagle's medium with $10 \%$ or $5 \%$ fetal calf serum, respectively. Cells were incubated at $37^{\circ} \mathrm{C}$ in a $5 \%$ or $10 \%$ (fibroblasts) $\mathrm{CO}_{2}$ atmosphere.

\subsection{Drug treatment and biological assays}

The synthesis and chemical structure of RPI-1 (1,3-dihydro-5,6-dimethoxy-3-[(4hydrophenyl)methylene]1-H-indol-2-one) were previously reported [13]. Stock solutions were prepared in DMSO and diluted in culture medium for use (final concentration of DMSO 0.25\%, even in controls). Cells were treated with the drug the day after splitting.

Cell viability was assessed by the Trypan blue dye exclusion assay or, alternatively, by the MTT (3-[4,5-dimethylthiazol-2-yl]-2,5-diphenyltetrazolium bromide) assay, measuring dye absorbance at $550 \mathrm{~nm}$. $\mathrm{IC}_{50}$ values (drug concentrations producing $50 \%$ inhibition) were calculated from dose-response curves. Where indicated, aFGF (50 ng/ml, Sigma Chemical Company, St. Louis, MO) and heparin (100 $\mu \mathrm{g} / \mathrm{ml}$, Serva, Heidelberg, Germany) were added to the cell culture, $24 \mathrm{~h}$ after splitting.

Apoptosis was detected by the terminal deoxynucleotidyltransferase-mediated deoxyuridine triphosphate nick-end labeling (TUNEL) assay using the In Situ Cell Detection Kit Fluorescein (Roche, Manheim, Germany) according to the manufacturer's instructions. Samples 
were analyzed by flow cytometry using the Cell Quest software (Becton Dickinson, Mountain View, CA).

Invasion assay was performed as previously described [17]. Briefly, cells exposed to vehicle or RPI-1 for 24h, were transferred on a Matrigel-coated (BD Biosciences, San Jose CA) upper chamber of a Transwell system (Costar, Corning Inch., Corning, NY) in serum-free medium. Complete MM medium or conditioned MSCs medium was placed in the lower chamber. The drug was added in both upper and lower chambers at the same concentration used for cell pretreatment. Cells that invaded Matrigel were counted after $24 \mathrm{~h}$ of incubation at $37^{\circ} \mathrm{C}$. Statistical analyses were performed using Student's 2-tailed $t$ test. $\mathrm{P}$ value $<0.05$ was considered statistically significant.

\subsection{Immunoprecipitation and Western blot analysis}

Cells were processed for immunoprecipitation (FGFR3) or total protein extraction followed by Western blotting as previously described [15]. For immunoprecipitation of FGFR3, cell lysates were incubated with pre-swelled protein A-agarose resin (Sigma Chemical Company) and antiFGFR3 antibody (6 $\mu \mathrm{g}$ for each milligram protein of cell extract), for $2 \mathrm{~h}$ at $4^{\circ} \mathrm{C}$. Immunoprecipitates were then washed and eluted as described [15]. For biochemical analysis of FGF-induced effects, cells were previously serum starved for $24 \mathrm{~h}$, treated with RPI-1 for the indicated times, and then stimulated with recombinant human aFGF $(50 \mathrm{ng} / \mathrm{ml})$ and heparin $(10$ $\mu \mathrm{g} / \mathrm{ml})$, in the last $5 \mathrm{~min}$.

The polyclonal antibodies used were: FGFR3 (C-15), STAT3 (K-15), JAK2 (M-126), caspase-9 (H-83) and Mcl-1 (S-19) from Santa Cruz Biotechnology (Santa Cruz, CA); p44/42 ERKs, phospho-JAK2 (Y1007, Y1008) and PARP from Upstate Biotechnology (Lake Placid, NY); phospho-FGF-R (Y653/Y654), phospho-p44/42 ERKs (T202, Y204), phospho-AKT 
(S473), phospho-STAT3 (Y705) and cleaved caspase-3 from Cell Signaling Technology (Beverly, MA); caspase-8 and Bcl-X from BD Pharmingen (Franklin Lakes, NJ); AKT from BD Transduction Laboratories (Lexington, KY); survivin and BCMA from Abcam (Cambridge, United Kingdom); actin from Sigma. Monoclonal antibodies were: c-Myc (9E10) from Santa Cruz, Kip1/p27 from BD Transduction Laboratories; phosphotyrosine (pY, clone 4G10) from Upstate, and $\beta$-tubulin from Sigma.

\subsection{Microarray data analysis}

Total RNA extraction and purification, biotin-labeled cRNA synthesis, fragmentation and hybridization on HG-U133A Probe Arrays and arrays scanning were performed as previously described $[19,20]$. Samples from 3 independent replicas for each time point were profiled. The probe level data were converted to expression values using the MAS 5.0 algorithm, and the normalization was performed using the 'global scaling' procedure, which normalizes the signals of different experiments to the same target intensity. Supervised gene expression analyses were performed using the Gene@Work software platform, which is a gene expression analysis tool based on the pattern discovery algorithm Structural Pattern Localization Analysis by Sequential Histograms (SPLASH). Genes@Work discovered global gene expression 'signatures' that were common to an entire set of at least $n$ experiments (the support set), where $n$ was a user-selectable parameter called the minimum support [20,21]. Full support and the value of $\delta=0.02$ were chosen for the analysis. For each gene, the statistical significance of the differential expression across the phenotype and control sets (gene z-score, $\mathrm{zg}$ ) was computed as previously described [20]. The selected probe list was visualized by means of DNAChip Analyzer (dChip) software [22]. The functional analysis on the selected lists was performed using the Database for 
Annotation, Visualization and Integrated Discovery (DAVID) Tool 2008 (U.S. National Institutes of Health) ${ }^{1}$ and NetAffx (Affymetrix $)^{2}$.

\section{Results}

\subsection{Effects of RPI-1 on HMCLs viability}

We investigated the effects of the tyrosine kinase inhibitor RPI-1 on a panel of HMCLs, four of which characterized by aberrant expression of FGF-R3 as a consequence of the $t(4 ; 14)$ translocation (Table 1). Among the $\mathrm{t}(4 ; 14)$ positive cell lines, OPM2 and KMS11 harbor FGF-R3 activating mutations, KMS18 has a non-transforming mutation, whereas KMS28 expresses a wild type FGF-R3 [7,23]. Representative dose-response and time-course inhibition curves obtained in cell viability assays are reported in Figures 1A and 1B. OPM2 and KMS11 cells were the most sensitive to the inhibitory effect of RPI-1. The two t(4;14) negative cell lines, KMS20 and JJN3, as well as KMS18 and KMS28 which harbor an FGF-R3 functionally silent in cell culture in basal conditions [7], showed lesser sensitivity (Table 1). However, cell growth enhancement of KMS18 induced by the specific FGF-R3 ligand, aFGF, was abrogated by RPI-1 treatment (Fig. 1C). The additional $t(14 ; 16)$ chromosome translocation present in KMS11 cells [23] did not appear to influence sensitivity to RPI-1, since the same genetic lesion is present in the less sensitive JJN3 cell line.

\subsection{Inhibition of FGF-R $3^{Y 373 C}$ in NIH3T3 transfectants}

To determine whether the high sensitivity of KMS11 and OPM2 cells was related to RPI-1 ability to interfere with FGF-R3 oncogenic activation, we first examined the effects of the drug on 
NIH3T3 fibroblasts stably transfected with the FGF-R ${ }^{\mathrm{Y} 373 \mathrm{C}}$ mutant present in the KMS11 cell line (A6-KMS11 cells) [7]. Upon treatment with RPI-1, FGF-R3 tyrosine phosphorylation was abolished and its expression was reduced in a dose-dependent manner (Fig. 2A). The drug effect on the receptor levels was confirmed by direct immunoblot detection in whole-cell lysates. Consistent with the abrogation of the receptor oncogenic function, RPI-1 induced a reversion of the transformed morphology of A6-KMS11 cells (not shown).

\subsection{Inhibition of FGF-R3- and JAK2-dependent signaling in HMCLs}

The effect of RPI- 1 was then examined in KMS11 cells expressing endogenous FGF-R3 ${ }^{\text {Y373C }}$. As observed in A6-KMS11 fibroblasts, drug treatment resulted in a marked dose-dependent inhibition of the receptor tyrosine phosphorylation and expression (Fig. 2B) which was achieved in the range of antiproliferative drug concentrations (3-30 $\mu \mathrm{M}$ corresponding to $\mathrm{IC}_{20}-\mathrm{IC}_{80}$, Fig. 1). Since FGF-R3 ${ }^{\mathrm{Y} 373 \mathrm{C}}$ maintains biochemical responsiveness to the ligand [7], we examined the effects of RPI-1 on the receptor signaling activation in aFGF-stimulated cells. Tyrosine phosphorylation of FGF-R3 ${ }^{\mathrm{Y} 373 \mathrm{C}}$ under serum starvation confirmed its constitutive activation (Fig. 2C). Stimulation with aFGF enhanced the receptor signaling as indicated by the increased phosphorylation of the receptor and of the downstream transducers ERKs and AKT. Pretreatment with RPI-1 abolished aFGF-induced activation of FGF-R3 ${ }^{\mathrm{Y} 373 \mathrm{C}}$, weakly reduced the receptor expression and inhibited the ligand-induced activation of ERKs and AKT, in a dose-dependent manner (Fig. 2C).

According to previous reports [7,24], the constitutive activation of STAT3 in KMS11 cells was not increased by aFGF stimulation. Nonetheless, STAT3 activation was inhibited by RPI-1 treatment (Fig. 2C) thus suggesting that the drug could affect JAK2, a major receptorassociated tyrosine kinase involved in cytokine intracellular signaling mediated by STAT3 in 
myeloma cells including KMS11 [24]. Indeed, drug treatment inhibited JAK2 activation which is constitutive in these cells (Fig. 2D). Both JAK2 and STAT3 were completely dephosphorylated in cells exposed to RPI-1 for $24 \mathrm{~h}$, whereas their expression was not affected even with more prolonged treatments (not shown).

\subsection{Apoptosis induction}

Because activation of signaling pathways dependent on both FGF-R3 and JAK2 is supposed to play a major role in sustaining MM cell survival [9], we examined whether RPI-1 treatment resulted in KMS11 cell death. As determined by TUNEL assay, drug treatment increased the number of apoptotic cells in the KMS11 cell population in a dose-dependent manner (Fig. 3A). Apoptosis was associated with the inhibition of AKT and STAT3 activation and with the downregulation of survivin and the Bcl-2 family member Bcl- $\mathrm{X}_{\mathrm{L}}$ (Fig. 3B), known as survival factors in myeloma cells $[9,25]$. Expression levels of Bcl-2 were not affected by drug treatment (not shown). Likewise, the global expression of Mcl-1, another key regulator of MM survival belonging to the Bcl-2 family [9], was not reduced although an increased detection of two low molecular weight peptides by the anti-Mcl-1 antibody in treated cells (Fig. 3B) suggested the occurrence of truncated pro-apoptotic forms of Mcl-1 [26]. The involvement of both intrinsic and extrinsic apoptotic pathways in cell response to RPI-1 was confirmed by the cleavage of caspases 8,9 , and 3 , and of the caspase substrate PARP. These effects were already detectable at $24 \mathrm{~h}$ (not shown) and still evident at $72 \mathrm{~h}$ of cell exposure to the drug (Fig. 3B).

\subsection{Gene expression profiling}

To gain further insights into the mechanisms of RPI-1 activity in HCMLs, we compared the gene expression profile (GEP) of KMS11 cells prior to and after treatment. The supervised analysis of 
GEP data revealed, after 24 h-exposure to RPI-1, a total of 92 probe sets differentially expressed, corresponding to 22 upregulated and 52 downregulated genes (Supplementary Data, Tables $3 \mathrm{a}$ and 3b). Functional stratification (Fig. 4) evidenced the downregulation of genes involved in sucrose (ALDOA, SORD, ME2, GPI, PYGB), fatty acid (FABP5, SCD, MECR), protein (IARS), and nucleotide (PAICS, NME1, and UCK2) metabolism, in agreement with a decreased cellular growth. Accordingly, genes devoted to mRNA splicing (SFRS1-2-3-7, SNRPF), rRNA processing (RRP9, EXOSC4), and translation initiation (EIF1, EIF3S8, EIF4a1, BZW2) were also significantly downregulated in KMS11-treated cells. In addition, we evidenced the downregulation of genes encoding receptors (BCMA/TNFRSF17, FGFR3), chaperone proteins (HSPA8, HSP90B1, HSPDI , HSPE1), and the transcription factor MYC. Conversely, among the overrepresented genes we identified other transcription factors ( $J U N, J U N-D, A T F 3$ and KLF4), and histones. Notably, spermidine/spermine N(1)-acetyltransferase gene (SAT-1) and spermidine synthase (SRM), two genes involved in the polyamines metabolism, were respectively up- and downregulated.

With the aim of identifying genes and/or pathways early deregulated by RPI-1, we performed the supervised analysis of GEP data from KMS11 samples upon 6 and 15 hours of treatment (Supplementary Data, Tables 1 and 2). Remarkably, analysis at $6 \mathrm{~h}$ pointed out the downregulation of $M I P-1 \alpha$ and MIP-1 $\beta$ (macrophage inflammatory protein 1-alpha and -beta, chemokine c-c motif ligand 3 and 4) which encode crucial chemokines involved in the development of osteolytic bone lesions as well as in growth, survival and migration in MM [27,28] (Fig. S1 and Table 1b in Supplementary Data). In addition, we found that several histones, splicing factors (SFRS1-3), SAT1, MYC, and BCMA, a B-cell specific TNF receptor family member involved in cell growth and survival regulation of MM [29], were significantly 
deregulated starting from $6 \mathrm{~h}$ of RPI-1 treatment (Fig. 4). FGF-R3 transcript was significantly downregulated at $15 \mathrm{~h}$, although a negative expression trend was already detectable at $6 \mathrm{~h}$ (Supplementary Data, Fig. S1 and Table 2b). Genes involved in metabolic processes were downregulated starting from $15 \mathrm{~h}$, whereas genes encoding heat shock proteins were mostly downregulated upon RPI-1 exposure for 24h (Fig. 4). Again, the analysis of all samples of RPI-1treated cells without any temporal segregation, revealed the deregulation of a significant fraction $(\mathrm{P}<0.001)$ of genes involved in the MAP kinase signaling pathway, thus confirming the strong impact exerted by the drug on downstream pathways controlling cell proliferation/survival (Tables 1-3 in Supplementary Data).

Validation at the protein level of some of the transcripts modulated upon RPI-1 treatment was performed by Western blot analysis. FGF-R3 downregulation was already detectable after $6 \mathrm{~h}$ of treatment and appeared preceded by a decrease in tyrosine phosphorylation (Fig. 5A). Inhibition of JAK2 phosphorylation followed similar kinetics, although JAK2 transcript/protein expression was not modulated by drug treatment (data not shown and Fig. 5A). A decrease in BCMA protein levels was evident starting from 15h of RPI-1 treatment (Fig. 5B) whereas Myc downregulation was already detectable at $6 \mathrm{~h}$ (Fig. 5C). Since Myc is known to suppress the expression of $\mathrm{p} 27^{\mathrm{Kip} 1}$ through different mechanisms [30], we also examined the protein levels of this cyclin-dependent kinase inhibitor. RPI-1-induced Myc downregulation was in fact reflected in $\mathrm{p} 27^{\mathrm{Kip} 1}$ upregulation at any time point (Fig. 8C). Such an opposite effect of RPI-1 on Myc and $\mathrm{p} 27^{\mathrm{Kip} 1}$ expression, together with the modulation of other cell cycle regulators $(\mathrm{p} 21$ and CDC25A) and histone family members (Tables 1-3 in Supplementary Data), strongly suggested a cell-cycle arrest of treated cells at the G1/S boundary [31]. Dose-response experiments (Figures 5B and 5C) provided further validation of protein expression modulations in KMS11 cells. Inhibition of JAK2 tyrosine phosphorylation and downregulation of BCMA and Myc, were also 
observed in KMS18 cells, thus indicating that these RPI-1 effects are not restricted to the KMS11 myeloma cell line (Supplementary Data, Fig. S2).

3.6. Inhibition of cell growth and Matrigel invasion induced by conditioned medium from mesenchymal stromal cells (MSCs)

The concomitant inhibition of FGF-R3, JAK2/STAT3, and BCMA signaling pathways in RPI-1treated KMS11 cells suggested a potential ability of the drug to interfere with the tumor cell response to stimuli provided by the BM microenvironment. To explore such issue, we tested the effects of RPI-1 on the MM cells in the presence of culture medium conditioned by BM-derived MSCs (Fig. 6). The conditioned medium significantly increased either cell growth or the cell ability to invade an artificial extracellular matrix such as Matrigel; in both assays, the enhancement was abrogated by RPI-1 treatment (Figures 6A and 6B). Similarly, at the biochemical level, increased STAT3 activation induced by the MSCs' conditioned medium was abrogated (Fig. 6C). Whereas dose-dependent inhibition of KMS11 cell growth was maintained even in the MSC medium, the growth of the MSCs was not significantly affected by the drug (not shown).

\section{Discussion}

MM is characterized by complex heterogeneous cytogenetic abnormalities [2]. In cooperation with the driving tumorigenic effects of genetic lesions within $\mathrm{MM}$ cells, the $\mathrm{BM}$ microenvironment provides essential support to the propagation and expansion of malignant clones and promotes drug resistance $[8,26,32]$. Based on such evidence, concomitant targeting of intrinsically-deregulated and BM microenvironment-sustained proliferation/survival pathways 
may offer a new exploitable treatment strategy in $\mathrm{MM}[8,10,26]$. The present study indicates that such a goal may be approached by a single multi-target agent. In fact, the 2 -indolinone tyrosine kinase inhibitor RPI-1 was shown to inhibit both FGF-R3, aberrantly expressed in $\mathrm{t}(4 ; 14)$ harboring MM cells, and JAK2, a major effector of IL-6 signaling. Moreover, analysis of GEP in RPI-1-treated cells revealed the downregulation of BCMA, a B-cell-specific receptor of growth factors that regulate growth and survival of MM. Thereby, three crucial signaling pathways, either dependent on oncogene activation or regulated by the BM microenvironment, were abrogated by drug treatment in MM cells.

Sensitivity to RPI-1 was higher in cells expressing an activated FGF-R3. These findings are consistent with previous reports with other FGF-R3 inhibitors indicating a strong dependence of KMS11 and OPM2 cells on constitutive FGF-R3 signaling for proliferation/survival [33-35]. However, the RPI-1 ability to abrogate KMS18 cell growth enhancement provided by aFGF, suggests a potential benefit extended to $t(4 ; 14)$ MM not expressing a constitutively active FGFR3. Our data indicate that the mechanism of FGF-R3 inhibition by RPI-1 may differ from that of other tyrosine kinase inhibitors. Indeed, RPI-1-induced FGF-R3 inactivation was achieved through both kinase inhibition and expression downregulation as detected at both RNA and protein level. This could be a peculiar aspect of the mechanism of receptor tyrosine kinase inactivation by this drug, because similar effects were observed on Ret and Met [15-17]. Although elucidating the molecular bases of such RPI-1 mechanism of action was out of the aim of this study, it is worth noting that JAK2 protein expression, similarly to other cytoplasmic tyrosine kinases such as the Ret/ptcs oncoproteins $[13,14]$ was not modulated by drug treatment, thus suggesting a differential target-dependent modality of tyrosine kinase inactivation.

GEP showed that RPI-1 treatment of KMS11 cells modulated genes recently described as specific components of the FGF-R3 activation pathways such as $S A T-1, A T F 3$ and $M I P-1 \alpha / 1 \beta$ 
[36]. In particular, we observed a concordant modulation at every time point of $S A T-1$ and $S R M$, both involved in the cellular polyamine metabolism [37]. The concerted up and downregulation of the catabolic $S A T-1$ and the biosynthetic $S R M$ enzyme, respectively, is expected to result in a reduction of the cellular polyamine pools, a condition associated with growth inhibition and apoptosis [38]. Indeed, targeting the polyamine pathway may have clinical relevance in anticancer therapy ${ }^{3}$. The upregulation of $A T F 3$ induced by drug treatment may be relevant in antimyeloma therapy as ATF3 is known to inhibit IL-6 and IL-12B transcription by altering chromatin structure and restricting access to transcription factors [39]. In addition, RPI-1 led to early downregulation of $M I P-1 \alpha$ and $M I P-1 \beta$, two chemokines produced by MM cells and implicated in the pathogenesis of myeloma bone disease $[27,28]$. Besides its role in development of osteolytic bone destruction, MIP-1 $\alpha$ might play a pivotal role in the pathogenesis of MM directly affecting cell signaling pathways that mediate growth, survival, and migration in $\mathrm{MM}$ cells and promoting adhesive interactions between MM and stromal cells [27]. Consistent with the potential implication of DUSP family in FGF-R3 signaling [36], GEP of RPI-1-treated cells also revealed the upregulation of DUSP10, a negative regulator of the MAP kinase cascade. Noteworthy, RPI-1 treatment downregulated also SFRS1, a splicing factor-encoding gene recently described as a proto-oncogene and a potential target for cancer therapy [40].

We show here that, together with FGF-R3, JAK2 is an RPI-1 target in MM cells. The potential therapeutic relevance of JAK2 in the treatment of MM is well recognized and related to its role as an effector of the signaling cascade induced by IL-6, a major growth and anti-apoptotic factor implicated in both autocrine and paracrine $\mathrm{MM}$ cell stimulation within the $\mathrm{BM}$ milieu $[8,12,41]$. It has been reported that IL-6 also participate to the regulation of BCMA expression [42], thus the early and stable downregulation of this receptor detected in KMS11 cells after RPI- 
1 treatment was conceivably an indirect effect of JAK2/STAT3 pathway inhibition. Accordingly, drug treatment inhibited JAK2 and downregulated BCMA also in KMS18 cells. Several lines of evidence point to BCMA as a potential therapeutic target in MM [43]. It represents indeed a major receptor of the two myeloma cell growth/survival factors, B cell-activating factor (BAFF) and a proliferation-inducing ligand (APRIL), produced by the BM MSCs [29]. A role for BAFF/BCMA signaling has been established in interaction and adhesion of MM cells with BM stromal cells [44]. Moreover, studies in $\mathrm{BCMA}^{-/-}$mice indicate a pivotal role for the receptor in the survival of long-lived BM plasma cells [45] and high levels of BCMA have been found in malignant plasma cells [46].

RPI-1 showed the ability to overcome proliferation and pro-invasive stimuli provided to MM cells by BM-derived MSCs. These findings support that the concomitant inhibition of FGFR3, JAK2/STAT3 and BCMA signaling pathways may, at least in part, counteract MM cell growth, survival and invasive stimuli sustained by the BM microenvironment. Our in vitro data indicate that the abrogation of growth factor-mediated signaling cascades was reflected in the inhibition of downstream pathways involving ERKs, AKT and STAT3. As a result, a perturbation of cell cycle progression, as suggested by the modulation of cell cycle regulators including Myc, p27 ${ }^{\mathrm{Kip} 1}$, p21 and CDC25A, was associated with caspase-dependent apoptosis. Further analysis of the determinants of RPI-1-induced cell death showed that drug treatment affected two additional proteins implicated in the MM pathobiology, Mcl-1 and survivin, both functioning as key regulators of cell survival [25,47]. Apoptosis was in fact characterized by increased detection of low molecular weight forms of Mcl-1 and downregulation of survivin. The generation of pro-apoptotic peptides by caspase-dependent cleavage of Mcl-1 has been described as an effective mechanism contributing to MM cell apoptosis even in the absence of substantial reduction of full-length Mcl-1 levels [26]. Nonetheless, because these peptides could be observed 
even in untreated cells, the expression of alternatively spliced forms of Mcl-1 cannot be ruled out [48]. The decrease in survivin expression, which was not appreciated at RNA level, was likely a consequence of PI3K/AKT pathway inhibition, as previously shown by specific AKT inhibition in the MM cell context [32]. Notably, modulation of Mcl-1 and survivin, as well as AKT, may have therapeutic relevance in this disease $[25,47,49]$.

A number of tyrosine kinase inhibitors targeting FGF-R3 or JAK2 have shown antimyeloma activity in preclinical studies $[33,34,35,41,50]$ and a few of them are currently being evaluated in phase I/II clinical trials in patients with relapsed or refractory $\mathrm{MM}^{3}$. The peculiar FGF-R3/JAK2 targeting profile exhibited by RPI-1 shows the feature to counteract multiple stimuli in $\mathrm{MM}$ cells, deriving by either the specific genetic alteration or the $\mathrm{BM}$ microenvironment. These findings provide a rationale for the development of treatment strategies resulting in a concomitant inhibition of FGF-R3 and JAK2 kinase signaling. Such therapeutic approaches may have relevance in $\mathrm{t}(4 ; 14)$ positive $\mathrm{MM}$ which represents the highest risk prognostic variant $[3,4]$ and may potentially contribute to overcoming resistance to conventional therapy. 


\section{Acknowledgements}

This study was supported in part by Associazione Italiana per la Ricerca sul Cancro to AN and FZ, Ministero della Salute and Alleanza Contro il Cancro. The authors thank the Medicinal Chemistry Department of Cell Therapeutics, Inc., Europe (Bresso, Italy), for the synthesis of RPI-1, Luigia Lombardi for critical review and Laura Zanesi for help in editing the manuscript.

\section{Disclosure of potential conflicts of interest}

The authors reported no potential conflicts of interest. 


\section{References}

[1] Hideshima T, Mitsiades C, Tonon G, Richardson PG, Anderson KC. Understanding multiple myeloma pathogenesis in the bone marrow to identify new therapeutic targets. Nature Rev 2007; 7:585-98.

[2] Chng WJ, Glebov O, Bergsagel PL, Kuehl WM. Genetic events in the pathogenesis of multiple myeloma. Best Pract Res Clin Haematol 2007; 20:571-96.

[3] Richelda R, Ronchetti D, Baldini L, Cro L, Viggiano L, Marzella R, et al. A novel chromosomal translocation $\mathrm{t}(4 ; 14)(\mathrm{p} 16.3 ; \mathrm{q} 32)$ in multiple myeloma involves the fibroblast growth-factor receptor 3 gene. Blood 1997; 90:4062-70.

[4] Todoerti K, Ronchetti D, Agnelli L, Castellani S, Marelli S, Deliliers GL, et al. Transcription repression activity is associated with the type I isoform of the MMSET gene involved in $\mathrm{t}(4 ; 14)$ in multiple myeloma. Br J Haematol 2005; 131:214-8.

[5] Chesi M, Bergsagel PL, Kuehl WM. The enigma of ectopic expression of FGRF3 in multiple myeloma: a critical initiating event or just a target for mutational activation during tumor progression. Curr Opin Hematol 2002; 9:288-293.

[6] Onwuazor ON, Wen XY, Wang DY, Zhuang L, Masih-Khan E, Claudio J, et al. Mutation, SNP, and isoform analysis of fibroblast growth factor receptor 3 (FGFR3) in 150 newly diagnosed multiple myeloma patients. Blood 2003; 102:772-3.

[7] Ronchetti D, Greco A, Compasso S, Colombo G, Dell'Era P, Otsuki T, et al. Deregulated FGFR3 mutants in multiple myeloma cell lines with t(4;14): comparative analysis of Y373C, K650E and the novel G384D mutations. Oncogene 2001; 20:3553-62.

[8] Mitsiades CS, Mitsiades NS, Richardson PG, Munshi NC, Anderson KC. Multiple myeloma: a prototypic disease model for the characterization and therapeutic targeting of interaction between tumor cells and their local microenvironment. J Cell Biochem 2007; 
101:950-68.

[9] Van de Donk NWCJ, Lokhorst HM, Bloem AC. Growth factors and antiapoptotic signaling pathways in multiple myeloma. Leukemia 2005; 19:2177-85.

[10] Bommert K, Bargou RC, Stuhmer T. Signalling and survival pathways in multiple myeloma. Eur J Cancer 2006; 42:1574-80.

[11] Yasui H, Hideshima T, Richardson PG, Anderson KC. Novel therapeutic strategies targeting growth factor signaling cascades in multiple myeloma. $\mathrm{Br} \mathrm{J}$ Haematol 2006; $132: 385-97$.

[12] Podar K, Chauhan D, Anderson KC. Bone marrow microenvironment and the identification of new targets for myeloma therapy. Leukemia 2008; advanced online publication.

[13] Lanzi C, Cassinelli G, Pensa T, Cassinis M, Gambetta RA, Borrello MG, et al. Inhibition of transforming activity of the ret/ptc1 oncoprotein by a 2 -indolinone derivative. Int $\mathrm{J}$ Cancer 2000; 85:384-90.

[14] Lanzi C, Cassinelli G, Cuccuru G, Zaffaroni N, Supino R, Vignati S, et al. Inactivation of Ret/Ptc1 oncoprotein and inhibition of papillary thyroid carcinoma cell proliferation by indolinone RPI-1. Cell Mol. Life Sci 2003; 60:1449-59.

[15] Cuccuru G, Lanzi C, Cassinelli G, Pratesi G, Tortoreto M, Petrangolini G, et al. Cellular effects and antitumor activity of RET inhibitor RPI-1 on MEN2A-associated medullary thyroid carcinoma. J Natl Cancer Inst 2004; 96:1006-14.

[16] Petrangolini G, Cuccuru G, Lanzi C, Tortoreto M, Belluco S, Pratesi G, et al. Apoptotic cell death induction and angiogenesis inhibition in large established medullary thyroid carcinoma xenografts by Ret inhibitor RPI-1. Biochem Pharmacol 2006; 72:405-14.

[17] Cassinelli G, Lanzi C, Petrangolini G, Tortoreto M, Pratesi G, Cuccuru G, et al. Inhibition 
of c-Met and prevention of spontaneous metastatic spreading by the 2-indolinone RPI-1. Mol Cancer Ther 2006; 5:2388-97.

[18] Cassinelli G, Favini E, Degl'Innocenti D, Salvi A, De Petro G, Pierotti MA, et al. RET/PTC1-driven neoplastic transformation and pro invasive phenotype of human thyrocytes involve Met induction and $\beta$-catenin nuclear translocation. Neoplasia 2009; $11: 10-21$

[19] Agnelli L, Bicciato S, Mattioli M, Fabris S, Intini D, Verdelli D, et al. Molecular classification of multiple myeloma: a distinct transcriptional profile characterizes patients expressing CCND1 and negative for 14q32 translocations. J Clin Oncol 2005; 23:7296306.

[20] Mattioli M, Agnelli L, Fabris S, Baldini L, Morabito F, Bicciato S, et al. Gene expression profiling of plasma cell dyscrasias reveals molecular patterns associated with distinct IGH translocations in multiple myeloma. Oncogene 2005; 24:2461-73.

[21] Klein U, Tu Y, Stolovitzky GA, Mattioli M, Cattoretti G, Husson H, et al. Gene expression profiling of B cell chronic lymphocytic leukemia reveals a homogeneous phenotype related to memory B cells. J Exp Med 2001; 194:1625-38.

[22] Schadt EE, Li C, Ellis B, Wong WH. Feature extraction and normalization algorithms for high-density oligonucleotide gene expression array data. J Cell Biochem Suppl 2001; $37: 120-5$

[23] Lombardi L, Poretti G, Mattioli M, Fabris S, Agnelli L, Bicciato S, et al. Molecular characterization of human multiple myeloma cell lines by integrative genomics: insights into the biology of the disease. Genes, Chromosomes \& Cancer 2007; 46:226-38.

[24] Ishikawa H, Tsuyama N, Liu S, Abroun S, Li F-J, Otsuyama K-i, et al. Accelerated proliferation of myeloma cells by interleukin-6 cooperating with fibroblast growth factor 
receptor 3-mediated signals. Oncogene 2005; 24:6328-32.

[25] Romagnoli M, Trichet V, David C, Clement M, Moreau P, Bataille R, et al. Significant impact of survivin on myeloma cell growth. Leukemia 2007; 21:1070-8.

[26] Podar K, Gouill SL, Zhang J, Opferman JT, Zorn E, Tai YT, et al. A pivotal role for Mcl1 in bortezomib-induced apoptosis. Oncogene 2008; 27:721-31.

[27] Terpos E, Politou M, Viniou N, Rahemtulla A. Significance of macrophage inflammatory protein-1 alpha (MIP-1alpha) in multiple myeloma. Leuk Lymphoma 2005; 46:1699-707.

[28] Hashimoto T, Abe M, Oshima T, et al. Ability of myeloma cells to secrete macrophage inflammatory protein (MIP)-1alpha and MIP-1beta correlates with lytic bone lesions in patients with multiple myeloma. Br J Haematol 2004; 125:38-41.

[29] Novak AJ, Darce JR, Arendt BK, Harder B, Henderson K, Kindsvogel W, et al. Expression of BCMA, TACI, and BAFF-R in multiple myeloma: a mechanism for growth and survival. Blood 2004; 103:689-94.

[30] Keller UB, Old JB, Dorsey FC, Nilsson JA, Nilsson L, MacLean KH, et al. Myc targets Cks1 to provoke the suppression of $\mathrm{p} 27^{\mathrm{Kip} 1}$, proliferation and lymphomagenesis. EMBO J $2007 ; 26: 2562-74$.

[31] Ewen ME. Where the cell cycle and histones meet. Genes Dev 2000; 14:2265-70.

[32] Hideshima T, Catley L, Raje N, Chauhan D, Podar K, Mitsiades C, et al. Inhibition of Akt induces significant downregulation of surviving and cytotoxicity in human multiple myeloma cells. Br J Haematol 2007; 138:783-91.

[33] Grand EK, Chase AJ, Heath C, Rahemtulla A, Cross NCP. Targeting FGFR3 in multiple myeloma: inhibition of t(4;14)-positive cells by SU5402 and PD173074. Leukemia 2004; 18:962-6.

[34] Trudel S, Li ZH, Wei E, Wiesmann M, Chang H, Chen C, et al. CHIR-258, a novel, 
multitargeted tyrosine kinase inhibitor for the potential treatment of $t(4 ; 14)$ multiple myeloma. Blood 2005; 105:2941-8.

[35] Bisping G, Kropff M, Wenning D, Dreyer B, Bessonov S, Hilberg F, et al. Targeting receptor kinases by a novel indolinone derivative in multiple myeloma: abrogation of stroma-derived interleukin-6 secretion and induction of apoptosis in cytogenetically defined subgroups. Blood 2006; 107:2079-89.

[36] Masih-Khan E, Trudel S, Heise C, Li Z, Paterson J, Nadeem V, et al. MIP-1alpha (CCL3) is a downstream target of FGFR3 and RAS-MAPK signaling in multiple myeloma. Blood 2006; 108:3465-71.

[37] Criss WE. A review of polyamines and cancer. Turk J Med Sci 2003; 33:195-205.

[38] Allen WL, McLean EG, Boyer J, McCulla A, Wilson PM, Coyle V, et al. The role of spermidine/spermine $\mathrm{N}^{1}$-acetyltransferase in determining response to chemotherapeutic agents in colorectal cancer cells. Mol Cancer Ther 2007; 6:128-37.

[39] Gilchrist M, Thorsson V, Li B, Rust AG, Korb M, Roach JC, et al. Systems biology approaches identify ATF3 as a negative regulator of Toll-like receptor 4. Nature 2006; $441: 173-8$.

[40] Karni R, de Stanchina E, Lowe SW, Sinha R, Mu D, Krainer AR. The gene encoding the splicing factor SF2/ASF is a proto-oncogene Nat Struct Mol Biol. 2007; 14:185-93.

[41] Pedranzini L, Dechow T, Berishaj M, Comenzo R, Zhou P, Azare J, et al. Pyridone 6, a pan-janus-activated kinase inhibitor, induces growth inhibition of multiple myeloma cells. Cancer Res 2006; 66:9714-21.

[42] Yang M, Hase H, Legarda-Addison D, Varughese L, Seed B, Ting AT. B cell maturation antigen, the receptor for a proliferation-inducing ligand and B cell-activating factor of the TNF family, induces antigen presentation in B cells. J Immunol 2005; 175:2814-24. 
[43] Ryan MC, Hering M, Peckham D, McDonagh CF, Brown L, Kim KM, et al. Antibody targeting of B-cell maturation antigen on malignant plasma cells. Mol Cancer Ther 2007; 6:3009-18.

[44] Tai Y-T, Li X-F, Breitkreutz I, Song W, Neri P, Catley L, et al. Role of B-cell-activating factor in adhesion and growth of human multiple myeloma cells in the bone marrow microenvironment. Cancer Res 2006; 66:6675-82.

[45] O'Connor BP, Raman VS, Erickson LD, Cook WJ, Weaver LK, Ahonen C, et al. BCMA is essential for the survival of long-lived bone marrow plasma cells. J Exp Med 2004; 199:91-7.

[46] Claudio JO, Masih-Khan E, Tang H, Goncalves J, Voralia M, Li ZH, et al. A molecular compendium of genes expressed in multiple myeloma. Blood 2002; 100:2175-86.

[47] Le Gouill S, Podar K, Harousseau J-L, Anderson KC. Mcl-1 regulation and its role in multiple myeloma. Cell Cycle 2004; 3:107-10.

[48] Gómez-Benito M, Martinez-Lorenzo MJ, Anel A, Marzo I, Naval J. Membrane expression of DR4, DR5 and caspase-8 levels, but not Mcl-1, determine sensitivity of human myeloma cells to Apo2L/TRAIL. Exp Cell Res 2007; 313:2378-88.

[49] Harvey RD, Lonial S. PI3 kinase/AKT pathway as a therapeutic target in multiple myeloma. Future Oncol 2007; 3:639-47.

[50] Chen J, Lee BH, Williams IR, Kutok JL, Mitsiades CS, Duclos N, et al. FGFR3 as a therapeutic target of the small molecule inhibitor PKC412 in hematopoietic malignancies. Oncogene 2005; 24:8259-67. 
1

2

3

4

5

\section{Web references}

\author{
${ }^{1}$ http://david.niaid.nih.gov/david/version2/index.htm \\ ${ }^{2}$ https://www.affymetrix.com/analysis/netaffx/ \\ ${ }^{3}$ http://www.clinicaltrials.gov
}




\section{Figure legends}

Figure 1. Effect of RPI-1 treatment on cell viability of representative HMCLs detected by Trypan blue dye exclusion assay. A, Mean dose-response curves obtained in at least two independent experiments (performed in duplicate) with KMS20, KMS11 and OPM2 cells incubated with the drug for $72 \mathrm{~h}$. Each point represents the mean percentage of the control viable cell number value. B, Time-course of growth inhibitory effect on KMS18 and KMS11 cell lines. Solvent or RPI-1 $(25 \mu \mathrm{M})$ were added to cell cultures the day after splitting (arrow). Viable cells were counted every day. Data (mean \pm SD) from one experiment representative of three is shown. C, Inhibition of cell growth enhancement induced by aFGF. KMS18 cells were treated with solvent (-) or $25 \mu \mathrm{M}$ RPI-1 (+) in the absence (-) or presence $(+)$ of aFGF/heparin as indicated. Viable cells were counted after $72 \mathrm{~h}$. Bars represent mean values \pm SD. One experiment representative of three is shown. $(*, \mathrm{P}<0.0005)$.

Figure 2. Inhibition of FGF-R3- and JAK2-mediated signaling by RPI-1. A, Inhibition of FGF$\mathrm{R} 3^{\mathrm{Y} 373 \mathrm{C}}$ constitutive activation and expression in NIH3T3 transfectants (A6-KMS11). Cells were treated with the indicated concentrations of the drug for $72 \mathrm{~h}$. Western blot analysis with anti-panphosphotyrosine (pTyr) or anti-FGF-R3 antibodies was performed on FGF-R3 immunoprecipitates (IP) or whole cell lysates (WCL) as indicated. In the lower panel, a cell lysate from NIH-3T3 parent cells was run in parallel as a negative control for FGF-R3 expression. B, Inhibition of endogenous FGF-R $3^{\mathrm{Y} 373 \mathrm{C}}$ tyrosine phosphorylation and expression in the HMCL KMS11. Cells were treated with RPI-1 (3, 10 and $30 \mu \mathrm{M})$ for $24 \mathrm{~h}$ and processed for Western blot analysis as in (A). C, Inhibition of aFGF-induced signaling in KMS11 cells. Serum 
starved cells were incubated in the presence of vehicle (-) or RPI-1 $(10$ or $30 \mu \mathrm{M})$ for $6 \mathrm{~h}$. Cells were then left untreated (-) or stimulated with aFGF/heparin (+) for $5 \mathrm{~min}$ as indicated. The activated status of receptor and downstream pathways was analyzed in cell lysates by Western blotting with phospho-specific antibodies recognizing activated FGF-R3, ERKs, AKT and STAT3. D, Inhibition of JAK2/STAT3 activation in KMS11 cells. Serum starved cells were treated with the indicated concentrations of the drug for $24 \mathrm{~h}$. Cell lysates were analyzed by Western blotting with phospho-specific antibodies recognizing activated JAK2 or STAT3. In (C) and (D), each blot was stripped and reprobed with the respective anti-protein antibodies. Protein loading is shown by actin.

Figure 3. Apoptosis induction by RPI-1 treatment in KMS11 cells. Cells were incubated in the presence of solvent (control) or RPI-1 $(10,20,30$ and $60 \mu \mathrm{M})$, for $72 \mathrm{~h}$. A, TUNEL assay analyzed by FACS. A representative dose-response experiment is shown together with quantitative data obtained in three independent experiments (panel right bottom). B, Modulation of anti-apoptotic factors and caspase activation. Cell lysates were analyzed by Western blotting to detect activating phosphorylations of AKT and STAT3, expression of Bcl- $\mathrm{X}_{\mathrm{L}}, \mathrm{Mcl}-1$ and survivin, and cleavage of caspases $(9,8$ and 3$)$ and PARP. Blots anti-pAKT and anti-pSTAT3 were stripped and reprobed with the respective anti-protein antibodies. Anti-tubulin blot shows protein loading. Quantitative data reported in $\mathbf{A}$ (panel right bottom) represent mean values of cell death induced by drug treatment both in $\mathbf{A}$ and $\mathbf{B}$. Histograms represent mean percentages of apoptotic cells \pm SD.

Figure 4. Supervised gene expression analysis comparing samples from triplicates of KMS11 cells treated with $30 \mu \mathrm{M}$ RPI-1 (T) or vehicle (C) for $24 \mathrm{~h}$. The expression levels of the identified 
genes in cells treated with RPI-1 for $6 \mathrm{~h}$ and $15 \mathrm{~h}$ are shown on the right side of the figure. Full support and $\delta$-value of 0.02 was used in the analysis. Genes differentially expressed in drugtreated vs control cells are grouped according to their functional categories and ranked within each category according to their $\mathrm{Zg}$ score. $\mathrm{Zg}$ scores and fold changes (FC) are expressed using the control group as baseline. The color scale bar represents the relative gene expression changes normalized by the standard deviation.

Figure 5. Modulation of selected gene products in KMS11 cells treated with RPI-1. Whole cell lysates were analyzed by Western blotting. In time-course experiments, cells were treated with solvent (-) or $30 \mu \mathrm{M}$ RPI-1 (+) for the indicated times. In the dose-response experiments shown in $\mathrm{B}$, and $\mathrm{C}$, cells were treated with solvent (-) or increasing drug concentrations $(3,10,30,60$ $\mu \mathrm{M})$ for 24h. A, Inhibition of FGF-R3 and JAK2 activation evidenced as abrogation of tyrosine phosphorylation (pFGF-R and pJAK2), and downregulation of FGF-R3 protein expression. B, Downregulation of BCMA expression. C, Downregulation of Myc and upregulation of p27 expression. Tubulin or actin blots are shown as controls for protein loading.

Figure 6. Abrogation of the stimulating effects of conditioned medium from mesenchymal stromal cells (MSCs) on cell growth and invasive properties of KMS11 cells by RPI-1 treatment. A, Cell viability assay. KMS11 cells cultured in the proper (MM) or MSCs-derived conditioned medium were treated with solvent (-) or the indicated concentrations of the drug for $72 \mathrm{~h}$. Cell viability was assessed by MTT colorimetric assay and expressed as optical density (OD) at 550 $\mathrm{nm}$. B, Invasion assay. Cells were exposed to $20 \mu \mathrm{M}$ RPI-1 for $24 \mathrm{~h}$ and then subjected to Matrigel invasion assay in the presence of the proper (MM) or MSCs-derived medium. Invading 
cells were colored and counted under microscope. Bars represent mean values \pm SD. C, Inhibition of STAT3 activation. Cell lysates from cells treated as in $\mathbf{B}$, were subjected to Western blotting and probed with anti-phospho-STAT3 antibody (pSTAT3). The blot was then stripped and reprobed with anti-STAT3 antibody. Anti-actin blot shows protein loading. Data shown are representative of three independent experiments. $(*, \mathrm{P}<0.0005)$. 
Table 1. Antiproliferative effect of RPI-1 on human MM cell lines (HMCLs)

\begin{tabular}{|c|c|c|c|}
\hline HMCL* & $t(4 ; 14)$ & FGFR3 status & $\begin{array}{c}\text { RPI-1 } \\
\left(\mathrm{IC}_{50}, \mu \mathrm{M}\right)\end{array}$ \\
\hline OPM2 & + & K650E (kinase domain, activating) & $4.9 \pm 0.1(\mathrm{n}=2)$ \\
\hline KMS11 & + & Y373C (transmembrane, activating) & $10.8 \pm 0.8(\mathrm{n}=3)$ \\
\hline KMS18 & + & $\begin{array}{l}\text { G384D (transmembrane, } \\
\text { not transforming) }\end{array}$ & $36.3 \pm 9.9(n=5)$ \\
\hline KMS28 & + & wt & $27.6 \pm 8.6(n=4)$ \\
\hline KMS20 & - & - & $>45(\mathrm{n}=4)$ \\
\hline JJN3 & - & - & $32.4 \pm 6.8(n=3)$ \\
\hline
\end{tabular}

*KMS11 and JJN3 cell lines harbor the $\mathrm{t}(14 ; 16)$ translocation. OPM2 has a translocation involving MAFB gene at chromosome 20 together with an unidentified partner chromosome. KMS20 is negative for any known chromosome translocation (23). 


\section{Supplementary data.}

\section{Supervised analysis of KMS11 RPI-1-treated versus KMS11 untreated cells.}

Table 1a Twenty-six up-regulated probes in KMS11 upon 6h RPI-1-treatment, ordered by gene name.

\begin{tabular}{|c|c|c|c|c|c|}
\hline Probe ID & GENE & NAME & Biological Process & Zscore & FC \\
\hline 207623_at & $\mathrm{ABCF} 2$ & $\begin{array}{l}\text { ATP-binding cassette, sub- } \\
\text { family F (GCN20), member } 2\end{array}$ & transport & 10.186 & 8.8976898 \\
\hline 207571_x_at & C1orf38 & $\begin{array}{l}\text { chromosome } 1 \text { open reading } \\
\text { frame } 38\end{array}$ & cell adhesion & 16.365 & 4.1309401 \\
\hline 210785_s_at & C1orf38 & $\begin{array}{l}\text { chromosome } 1 \text { open reading } \\
\text { frame } 38\end{array}$ & cell adhesion & 7.812 & 3.7808393 \\
\hline 210689_at & CLDN14 & claudin 14 & $\begin{array}{l}\text { protein complex } \\
\text { assembly }\end{array}$ & 40.369 & 7.3953488 \\
\hline 204724_s_at & COL9A3 & collagen, type IX, alpha 3 & phosphate transport & 19.351 & 7.6466083 \\
\hline 203947_at & CSTF3 & $\begin{array}{l}\text { cleavage stimulation factor, } 3^{\prime} \\
\text { pre-RNA, subunit } 3,77 \mathrm{kDa}\end{array}$ & mRNA processing & 5.695 & 3.2016276 \\
\hline 219233_s_at & GSDML & gasdermin-like & & 9.505 & 4.3386628 \\
\hline 208579_x_at & $\begin{array}{l}\text { H2BFS / } \\
\text { HIST1H2BK }\end{array}$ & $\begin{array}{l}\mathrm{H} 2 \mathrm{~B} \text { histone family, member } \\
\mathrm{S} / \text { histone cluster } 1, \mathrm{H} 2 \mathrm{bk}\end{array}$ & nucleosome assembly & 8.257 & 4.1768187 \\
\hline 215071_s_at & HIST1H2AC & histone cluster $1, \mathrm{H} 2 \mathrm{ac}$ & nucleosome assembly & 10.437 & 6.0092814 \\
\hline 209806_at & HIST1H2BK & histone cluster $1, \mathrm{H} 2 \mathrm{bk}$ & nucleosome assembly & 9.692 & 2.8170327 \\
\hline 214522_x_at & HIST1H3D & histone cluster $1, \mathrm{H} 3 \mathrm{~d}$ & nucleosome assembly & 5.943 & 13.805085 \\
\hline 206110_at & HIST1H3H & histone cluster $1, \mathrm{H} 3 \mathrm{~h}$ & nucleosome assembly & 9.421 & 5.5302083 \\
\hline 214290_s_at & $\begin{array}{l}\text { HIST2H2AA3 / } \\
\text { HIST2H2AA4 }\end{array}$ & $\begin{array}{l}\text { histone cluster } 2, \mathrm{H} 2 \mathrm{aa} 3 \text { / } \\
\text { histone cluster } 2, \mathrm{H} 2 \mathrm{aa} 4\end{array}$ & nucleosome assembly & 9.957 & 2.4075915 \\
\hline 218280_x_at & $\begin{array}{l}\text { HIST2H2AA3 / } \\
\text { HIST2H2AA4 }\end{array}$ & $\begin{array}{l}\text { histone cluster } 2, \mathrm{H} 2 \mathrm{aa} 3 \text { / } \\
\text { histone cluster } 2, \mathrm{H} 2 \mathrm{aa} 4\end{array}$ & nucleosome assembly & 5.405 & 3.1270189 \\
\hline 213776_at & LOC 157562 & $\begin{array}{l}\text { hypothetical protein } \\
\text { LOC } 157562\end{array}$ & --- & 7.087 & 5.5628141 \\
\hline 213225_at & PPM1B & $\begin{array}{l}\text { protein phosphatase } 1 \mathrm{~B} \\
\text { (formerly } 2 \mathrm{C} \text { ), magnesium- } \\
\text { dependent, beta isoform }\end{array}$ & $\begin{array}{l}\text { protein amino acid } \\
\text { dephosphorylation }\end{array}$ & 4.272 & 4.6496815 \\
\hline 200749_at & RAN & $\begin{array}{l}\text { RAN, member RAS oncogene } \\
\text { family }\end{array}$ & $\begin{array}{l}\text { regulation of progression } \\
\text { through cell cycle }\end{array}$ & 4.917 & 3.2060944 \\
\hline 202388_at & RGS2 & $\begin{array}{l}\text { regulator of G-protein } \\
\text { signalling } 2,24 \mathrm{kDa}\end{array}$ & cell cycle & 25.048 & 5.1233576 \\
\hline 209070_s_at & RGS5 & $\begin{array}{l}\text { regulator of G-protein } \\
\text { signalling } 5\end{array}$ & $\begin{array}{l}\text { regulation of G-protein } \\
\text { coupled receptor protein } \\
\text { signaling pathway }\end{array}$ & 3.675 & 6.061828 \\
\hline 209071_s_at & RGS5 & $\begin{array}{l}\text { regulator of G-protein } \\
\text { signalling } 5\end{array}$ & $\begin{array}{l}\text { regulation of G-protein } \\
\text { coupled receptor protein } \\
\text { signaling pathway }\end{array}$ & 3.435 & 6.0876068 \\
\hline 212019_at & RSL1D1 & $\begin{array}{l}\text { ribosomal L1 domain } \\
\text { containing } 1\end{array}$ & translation & 6.581 & 4.9563427 \\
\hline
\end{tabular}




\begin{tabular}{|c|c|c|c|c|c|}
\hline 213750_at & RSL1D1 & $\begin{array}{l}\text { ribosomal L1 domain } \\
\text { containing } 1\end{array}$ & translation & 30.956 & 4.6814048 \\
\hline 203455_s_at & SAT1 & $\begin{array}{l}\text { spermidine/spermine N1- } \\
\text { acetyltransferase } 1\end{array}$ & metabolic process & 8.988 & 6.1119048 \\
\hline 210592_s_at & SAT1 & $\begin{array}{l}\text { spermidine/spermine N1- } \\
\text { acetyltransferase } 1\end{array}$ & metabolic process & 17.694 & 8.0817518 \\
\hline 213988_s_at & SAT1 & $\begin{array}{l}\text { spermidine/spermine N1- } \\
\text { acetyltransferase } 1\end{array}$ & metabolic process & 17.814 & 22.983871 \\
\hline 208078_s_at & SNF1LK & SNF1-like kinase & $\begin{array}{l}\text { negative regulation of } \\
\text { transcription from RNA } \\
\text { polymerase II promoter }\end{array}$ & 5.925 & 29859 \\
\hline
\end{tabular}


Table 1b Thirty-two down-regulated probes in KMS11 upon 6h RPI-1-treatment, ordered by gene name.

\begin{tabular}{|c|c|c|c|c|c|}
\hline Probe ID & GENE & NAME & Biological Process & Zscore & FC \\
\hline 40472_at & AGPAT7 & $\begin{array}{l}\text { 1-acylglycerol-3-phosphate O- } \\
\text { acyltransferase } 7 \text { (lysophosphatidic } \\
\text { acid acyltransferase, eta) }\end{array}$ & metabolic process & -8.254 & -5.815047022 \\
\hline 202760_s_at & AKAP2 & A kinase (PRKA) anchor protein 2 & regulation of cell shape & -8.9 & -4.634046053 \\
\hline 201084_s_at & BCLAF1 & BCL2-associated transcription factor 1 & regulation of transcription & -11.226 & -2.802586207 \\
\hline 201101_s_at & BCLAF1 & BCL2-associated transcription factor 1 & regulation of transcription & -8.748 & -8.460588794 \\
\hline 205114_s_at & $\begin{array}{l}\text { CCL3/ } \\
\text { MIP-1 } \alpha\end{array}$ & chemokine ( $\mathrm{C}-\mathrm{C}$ motif) ligand 3 & cell-cell signaling & -8.326 & -15.40503247 \\
\hline 204103_at & $\begin{array}{l}\text { CCL4/ } \\
\text { MIP-1 } \beta\end{array}$ & chemokine ( $\mathrm{C}-\mathrm{C}$ motif) ligand 4 & cell-cell signaling & -4.893 & -18.88023952 \\
\hline 204118_at & CD48 & CD48 molecule & defense response & -19.868 & -3.601732435 \\
\hline 202613_at & CTPS & CTP synthase & $\begin{array}{l}\text { nucleic acid metabolic } \\
\text { process }\end{array}$ & -10.976 & -3.289522919 \\
\hline 210137_s_at & DCTD & dCMP deaminase & $\begin{array}{l}\text { nucleic acid metabolic } \\
\text { process }\end{array}$ & -5.528 & -3.030553865 \\
\hline 212728_at & DLG3 & $\begin{array}{l}\text { discs, large homolog } 3 \\
\text { (neuroendocrine-dlg, Drosophila) }\end{array}$ & $\begin{array}{l}\text { regulation of cell } \\
\text { proliferation }\end{array}$ & -4.286 & -5.608200456 \\
\hline 203638_s_at & FGFR2 & fibroblast growth factor receptor 2 & $\begin{array}{l}\text { protein amino acid } \\
\text { phosphorylation; cell } \\
\text { growth }\end{array}$ & -4.72 & -4.882352941 \\
\hline 215967_s_at & LY9 & lymphocyte antigen 9 & cell adhesion & -18.782 & -16.10240964 \\
\hline 210017_at & MALT1 & $\begin{array}{l}\text { mucosa associated lymphoid tissue } \\
\text { lymphoma translocation gene } 1\end{array}$ & $\begin{array}{l}\text { positive regulation of } \mathrm{T} \\
\text { cell cytokine production }\end{array}$ & -5.145 & -4.302302302 \\
\hline 205447_s_at & MAP3K12 & $\begin{array}{l}\text { mitogen-activated protein kinase } \\
\text { kinase kinase } 12\end{array}$ & JNK cascade & -12.777 & -7.346774194 \\
\hline 200796_s_at & MCL1 & $\begin{array}{l}\text { myeloid cell leukemia sequence } 1 \\
\text { (BCL2-related) }\end{array}$ & regulation of apoptosis & -3.78 & -3.70783848 \\
\hline 202431_s_at & MYC & $\begin{array}{l}\text { v-myc myelocytomatosis viral } \\
\text { oncogene homolog (avian) }\end{array}$ & $\begin{array}{l}\text { regulation of cell } \\
\text { proliferation }\end{array}$ & -5.559 & -2.614602835 \\
\hline 222206_s_at & NCLN & nicalin homolog (zebrafish) & protein processing & -3.26 & -4.836400818 \\
\hline 209062_x_at & NCOA3 & nuclear receptor coactivator 3 & regulation of transcription, & -6.416 & -6.938080495 \\
\hline 203823_at & RGS3 & regulator of G-protein signalling 3 & $\begin{array}{l}\text { negative regulation of } \\
\text { signal transduction }\end{array}$ & -63.427 & -16.24761905 \\
\hline 216392_s_at & SEC23IP & SEC23 interacting protein & $\begin{array}{l}\text { intracellular protein } \\
\text { transport }\end{array}$ & -8.067 & -3.89797136 \\
\hline 208863_s_at & SFRS1 & $\begin{array}{l}\text { splicing factor, arginine/serine-rich } 1 \\
\text { (splicing factor 2, alternate splicing } \\
\text { factor) }\end{array}$ & mRNA processing & -13.795 & -3.635181383 \\
\hline 200754_x_at & SFRS2 & splicing factor, arginine/serine-rich 2 & mRNA processing & -3.142 & -2.358962421 \\
\hline 214882_s_at & SFRS2 & splicing factor, arginine/serine-rich 2 & mRNA processing & -4.696 & -2.673421819 \\
\hline
\end{tabular}




\begin{tabular}{|c|c|c|c|c|c|}
\hline 202899_s_at & SFRS3 & splicing factor, arginine/serine-rich 3 & mRNA processing & -21.044 & -3.214740252 \\
\hline 208672_s_at & SFRS3 & splicing factor, arginine/serine-rich 3 & mRNA processing & -9.737 & -3.032237266 \\
\hline 214141_x_at & SFRS7 & $\begin{array}{l}\text { splicing factor, arginine/serine-rich } 7 \text {, } \\
35 \mathrm{kDa}\end{array}$ & mRNA processing & -11.13 & -2.635012715 \\
\hline 206641_at & $\begin{array}{l}\text { TNFRSF17/ } \\
\text { BCMA }\end{array}$ & $\begin{array}{l}\text { tumor necrosis factor receptor } \\
\text { superfamily, member } 17\end{array}$ & $\begin{array}{l}\text { signal transduction; cell } \\
\text { proliferation }\end{array}$ & -9.737 & -8.782380952 \\
\hline 217853_at & TNS3 & tensin 3 & $\begin{array}{l}\text { intracellular signaling } \\
\text { cascade }\end{array}$ & -6.88 & -2.995089442 \\
\hline 213888_s_at & TRAF3IP3 & TRAF3 interacting protein 3 & --- & -9.883 & -3.752346194 \\
\hline 209013_x_at & TRIO & $\begin{array}{l}\text { triple functional domain (PTPRF } \\
\text { interacting) }\end{array}$ & $\begin{array}{l}\text { protein amino acid } \\
\text { phosphorylation }\end{array}$ & -3.818 & -5.736363636 \\
\hline 218245_at & TSKU & tsukushin & -- & -21.391 & -6.632727273 \\
\hline 202864_s_at & SP100 & SP100 nuclear antigen & $\begin{array}{l}\text { regulation of transcription, } \\
\text { DNA-dependent /// } \\
\text { regulation of transcription, } \\
\text { DNA-dependent }\end{array}$ & -11.799 & $-\overline{10.65128205}$ \\
\hline
\end{tabular}


Table 2a Twenty-four up-regulated probes in KMS11 upon 15h RPI-1-treatment, ordered by gene name.

\begin{tabular}{|c|c|c|c|c|c|}
\hline Probe ID & GENE & NAME & $\begin{array}{l}\text { Biological } \\
\text { Process }\end{array}$ & Zscore & FC \\
\hline 202284_s_at & CDKN1A & $\begin{array}{l}\text { cyclin-dependent kinase inhibitor } \\
1 \mathrm{~A}(\mathrm{p} 21, \mathrm{Cip} 1)\end{array}$ & $\begin{array}{l}\text { regulation of } \\
\text { progression through } \\
\text { cell cycle }\end{array}$ & 34.93 & 7.534413 \\
\hline 212227_x_at & EIF1 & $\begin{array}{l}\text { eukaryotic translation initiation } \\
\text { factor } 1\end{array}$ & translational initiation & 6.29 & 1.9578982 \\
\hline 204805_s_at & H1FX & H1 histone family, member X & nucleosome assembly & 2.638 & 2.4686474 \\
\hline 208579_x_at & $\begin{array}{l}\text { H2BFS/ } \\
\text { HIST1H2BK }\end{array}$ & $\begin{array}{l}\mathrm{H} 2 \mathrm{~B} \text { histone family, member S / } \\
\text { histone cluster } 1, \mathrm{H} 2 \mathrm{bk}\end{array}$ & nucleosome assembly & 4.448 & 3.1218202 \\
\hline 209398_at & HIST1H1C & histone cluster $1, \mathrm{H} 1 \mathrm{c}$ & nucleosome assembly & 3.163 & 2.5475938 \\
\hline 215071_s_at & HIST1H2AC & histone cluster $1, \mathrm{H} 2 \mathrm{ac}$ & nucleosome assembly & 5.702 & 4.8790942 \\
\hline 214469_at & HIST1H2AE & histone cluster $1, \mathrm{H} 2 \mathrm{ae}$ & nucleosome assembly & 3.045 & 5.6865672 \\
\hline 209806_at & HIST1H2BK & $\begin{array}{l}\text { H2B histone family, member S / } \\
\text { histone cluster } 1, \mathrm{H} 2 \mathrm{bk}\end{array}$ & nucleosome assembly & 8.498 & 2.4928358 \\
\hline 214472 at & HIST1H3D & histone cluster $1, \mathrm{H} 3 \mathrm{~d}$ & nucleosome assembly & 5.709 & 5.0259865 \\
\hline 208496_x_at & HIST1H3G & histone cluster $1, \mathrm{H} 3 \mathrm{~g}$ & nucleosome assembly & 21.75 & 25.422764 \\
\hline 206110_at & HIST1H3H & histone cluster $1, \mathrm{H} 3 \mathrm{~h}$ & nucleosome assembly & 9.351 & 6.0917793 \\
\hline 214290_s_at & $\begin{array}{l}\text { HIST2H2AA3 / } \\
\text { HIST2H2AA4 }\end{array}$ & $\begin{array}{l}\text { histone cluster } 2, \mathrm{H} 2 \mathrm{aa} 3 \text { / histone } \\
\text { cluster } 2, \mathrm{H} 2 \mathrm{aa} 4\end{array}$ & nucleosome assembly & 9.215 & 3.7411356 \\
\hline 218280_x_at & $\begin{array}{l}\text { HIST2H2AA3 / } \\
\text { HIST2H2AA4 }\end{array}$ & $\begin{array}{l}\text { histone cluster 2, H2aa3 / histone } \\
\text { cluster 2, H2aa4 }\end{array}$ & nucleosome assembly & 7.636 & 4.9598617 \\
\hline 200800_s_at & $\begin{array}{l}\text { HSPA1A / } \\
\text { HSPA1B }\end{array}$ & $\begin{array}{l}\text { heat shock } 70 \mathrm{kDa} \text { protein } 1 \mathrm{~A} / \text { heat } \\
\text { shock } 70 \mathrm{kDa} \text { protein } 1 \mathrm{~B}\end{array}$ & $\begin{array}{l}\text { mRNA catabolic } \\
\text { process }\end{array}$ & 3.834 & 5.115903 \\
\hline 202581_at & HSPA1B & $\begin{array}{l}\text { heat shock } 70 \mathrm{kDa} \text { protein } 1 \mathrm{~A} / \text { heat } \\
\text { shock } 70 \mathrm{kDa} \text { protein } 1 \mathrm{~B}\end{array}$ & $\begin{array}{l}\text { mRNA catabolic } \\
\text { process }\end{array}$ & 5.383 & 4.8661267 \\
\hline 117_at & HSPA6 & $\begin{array}{l}\text { heat shock 70kDa protein } 6 \\
\text { (HSP70B') }\end{array}$ & $\begin{array}{l}\text { response to unfolded } \\
\text { protein }\end{array}$ & 3.667 & 11.769097 \\
\hline 213418_at & HSPA6 & $\begin{array}{l}\text { heat shock 70kDa protein } 6 \\
\text { (HSP70B') }\end{array}$ & $\begin{array}{l}\text { response to unfolded } \\
\text { protein }\end{array}$ & 14.81 & 29.241055 \\
\hline 203752_s_at & JUND & jun D proto-oncogene & $\begin{array}{l}\text { regulation of } \\
\text { transcription }\end{array}$ & 5.955 & 2.2876192 \\
\hline 37028_at & PPP1R15A & $\begin{array}{l}\text { protein phosphatase } 1 \text {, regulatory } \\
\text { (inhibitor) subunit } 15 \mathrm{~A}\end{array}$ & apoptosis & 4.613 & 3.2170997 \\
\hline 202388_at & RGS2 & $\begin{array}{l}\text { regulator of G-protein signalling } 2 \text {, } \\
24 \mathrm{kDa}\end{array}$ & cell cycle & 3.926 & 2.9416775 \\
\hline 209070_s_at & RGS5 & regulator of G-protein signalling 5 & $\begin{array}{l}\text { regulation of G- } \\
\text { protein coupled } \\
\text { receptor protein } \\
\text { signaling pathway }\end{array}$ & 5.374 & 6.380805 \\
\hline 203455_s_at & SAT1 & $\begin{array}{l}\text { spermidine/spermine N1- } \\
\text { acetyltransferase } 1\end{array}$ & metabolic process & 7.052 & 5.8085774 \\
\hline 210592_s_at & SAT1 & $\begin{array}{l}\text { spermidine/spermine N1- } \\
\text { acetyltransferase } 1\end{array}$ & metabolic process & 17.427 & 7.6462054 \\
\hline 213988_s_at & SAT1 & $\begin{array}{l}\text { spermidine/spermine N1- } \\
\text { acetyltransferase } 1\end{array}$ & metabolic process & 21.964 & 25.180645 \\
\hline
\end{tabular}


Table 2b Twenty down-regulated probes in KMS11 upon 15h RPI-1-treatment, ordered by gene name.

\begin{tabular}{|c|c|c|c|c|c|}
\hline Probe ID & GENE & NAME & $\begin{array}{l}\text { Biological } \\
\text { Process }\end{array}$ & Zscore & FC \\
\hline 214358_at & ACACA & $\begin{array}{l}\text { acetyl-Coenzyme A carboxylase } \\
\text { alpha }\end{array}$ & metabolic process & -3.436 & -5.6089552 \\
\hline 209442_x_at & ANK3 & $\begin{array}{l}\text { ankyrin 3, node of Ranvier (ankyrin } \\
\text { G) }\end{array}$ & protein targeting & -4.27 & -3.5157164 \\
\hline 206185_at & CRYBB1 & crystallin, beta B1 & visual perception & -7.988 & -4.2361574 \\
\hline 219328_at & DDX31 & $\begin{array}{l}\text { DEAD (Asp-Glu-Ala-Asp) box } \\
\text { polypeptide } 31\end{array}$ & --- & -2.614 & -4.4198251 \\
\hline 218858_at & DEPDC6 & DEP domain containing 6 & $\begin{array}{l}\text { intracellular } \\
\text { signaling cascade }\end{array}$ & -9.712 & -3.065756 \\
\hline 201478_s_at & $\mathrm{DKC1}$ & dyskeratosis congenita 1 , dyskerin & cell proliferation & -2.895 & -3.575391 \\
\hline 216212_s_at & $\mathrm{DKC1}$ & dyskeratosis congenita 1 , dyskerin & cell proliferation & -4.984 & -10.615213 \\
\hline 202345_s_at & FABP5 & $\begin{array}{l}\text { fatty acid binding protein } 5 \\
\text { (psoriasis-associated) }\end{array}$ & $\begin{array}{l}\text { lipid metabolic } \\
\text { process }\end{array}$ & -5.756 & -2.9379077 \\
\hline 204379_s_at & FGFR3 & $\begin{array}{l}\text { fibroblast growth factor receptor } 3 \\
\text { (achondroplasia, thanatophoric } \\
\text { dwarfism) }\end{array}$ & MAPKKK cascade & -6.977 & -1.8886028 \\
\hline 214011_s_at & HSPC111 & hypothetical protein HSPC111 & --- & -4.307 & -3.6959191 \\
\hline 203931_s_at & MRPL12 & mitochondrial ribosomal protein L12 & translation & -2.904 & -2.6991798 \\
\hline 202431_s_at & MYC & $\begin{array}{l}\text { v-myc myelocytomatosis viral } \\
\text { oncogene homolog (avian) }\end{array}$ & $\begin{array}{l}\text { regulation of cell } \\
\text { proliferation }\end{array}$ & -6.505 & -3.564178 \\
\hline 217356_s_at & PGK1 & phosphoglycerate kinase 1 & glycolysis & -2.91 & -2.3751648 \\
\hline 205267_at & POU2AF1 & $\begin{array}{l}\text { POU domain, class } 2 \text {, associating } \\
\text { factor } 1\end{array}$ & transcription & -12.326 & -2.8488287 \\
\hline 218758_s_at & RRP1 & $\begin{array}{l}\text { ribosomal RNA processing } 1 \\
\text { homolog (S. cerevisiae) }\end{array}$ & rRNA processing & -3.647 & -6.4540682 \\
\hline 216913_s_at & RRP12 & $\begin{array}{l}\text { ribosomal RNA processing } 12 \\
\text { homolog (S. cerevisiae) }\end{array}$ & --- & -7.513 & -10.261146 \\
\hline 214141_x_at & SFRS7 & $\begin{array}{l}\text { splicing factor, arginine/serine-rich } \\
7,35 \mathrm{kDa}\end{array}$ & mRNA processing & -4.217 & -4.0526149 \\
\hline 201563_at & SORD & sorbitol dehydrogenase & $\begin{array}{l}\text { sorbitol metabolic } \\
\text { process }\end{array}$ & -16.606 & -5.0759429 \\
\hline 206641_at & $\begin{array}{l}\text { TNFRSF17/ } \\
\text { BCMA }\end{array}$ & $\begin{array}{l}\text { tumor necrosis factor receptor } \\
\text { superfamily, member } 17\end{array}$ & cell proliferation & -10.678 & -8.1686678 \\
\hline 209825_s_at & UCK2 & uridine-cytidine kinase 2 & $\begin{array}{l}\text { biosynthetic } \\
\text { process }\end{array}$ & -7.546 & -3.53289 \\
\hline
\end{tabular}


Table 3a Thirty-three up-regulated probes in KMS11 upon 24h RPI-1-treatment, ordered by gene name.

\begin{tabular}{|c|c|c|c|c|c|}
\hline Probe ID & GENE & NAME & Biological Process & Zscore & FC \\
\hline 202672_s_at & ATF3 & $\begin{array}{l}\text { activating transcription } \\
\text { factor } 3\end{array}$ & regulation of transcription & 8.525 & 5.1128641 \\
\hline 207571_x_at & C1orf38 & $\begin{array}{l}\text { chromosome } 1 \text { open } \\
\text { reading frame } 38\end{array}$ & cell adhesion & 10.231 & 3.1183007 \\
\hline 210785_s_at & C1orf38 & $\begin{array}{l}\text { chromosome } 1 \text { open } \\
\text { reading frame } 39\end{array}$ & cell adhesion & 5.492 & 3.1126835 \\
\hline 213348_at & CDKN1C & $\begin{array}{l}\text { cyclin-dependent kinase } \\
\text { inhibitor } 1 \mathrm{C}(\mathrm{p} 57, \mathrm{Kip} 2)\end{array}$ & $\begin{array}{l}\text { regulation of progression } \\
\text { through cell cycle }\end{array}$ & 8.117 & 4.3138486 \\
\hline 216894_x_at & CDKN1C & $\begin{array}{l}\text { cyclin-dependent kinase } \\
\text { inhibitor } 1 \mathrm{C}(\mathrm{p} 57, \mathrm{Kip} 2)\end{array}$ & $\begin{array}{l}\text { regulation of progression } \\
\text { through cell cycle }\end{array}$ & 6.458 & 4.5855327 \\
\hline 219534_x_at & CDKN1C & $\begin{array}{l}\text { cyclin-dependent kinase } \\
\text { inhibitor } 1 \mathrm{C}(\mathrm{p} 57, \mathrm{Kip} 2)\end{array}$ & $\begin{array}{l}\text { regulation of progression } \\
\text { through cell cycle }\end{array}$ & 6.017 & 3.8604513 \\
\hline 219640_at & CLDN15 & claudin 15 & $\begin{array}{l}\text { calcium-independent cell- } \\
\text { cell adhesion }\end{array}$ & 2.992 & 4.5110132 \\
\hline 215501_s_at & DUSP10 & $\begin{array}{l}\text { dual specificity } \\
\text { phosphatase } 10\end{array}$ & $\begin{array}{l}\text { protein amino acid } \\
\text { dephosphorylation; JNK } \\
\text { cascade }\end{array}$ & 2.94 & 4.2466539 \\
\hline 221563_at & DUSP10 & $\begin{array}{l}\text { dual specificity } \\
\text { phosphatase } 10\end{array}$ & $\begin{array}{l}\text { protein amino acid } \\
\text { dephosphorylation; JNK } \\
\text { cascade }\end{array}$ & 7.978 & 5.7436233 \\
\hline 212227_x_at & EIF1 & $\begin{array}{l}\text { eukaryotic translation } \\
\text { initiation factor } 1\end{array}$ & translational initiation & 2.567 & 1.7629325 \\
\hline 219233_s_at & GSDML & gasdermin-like & --- & 5.451 & 4.0514626 \\
\hline 215071_s_at & HIST1H2AC & histone cluster $1, \mathrm{H} 2 \mathrm{ac}$ & nucleosome assembly & 22.386 & 4.4343735 \\
\hline 214472_at & HIST1H3D & histone cluster $1, \mathrm{H} 3 \mathrm{~d}$ & nucleosome assembly & 11.537 & 4.9131915 \\
\hline 214522_x_at & HIST1H3D & histone cluster $1, \mathrm{H} 3 \mathrm{~d}$ & nucleosome assembly & 7.022 & 4.6964006 \\
\hline 208496_x_at & HIST1H3G & histone cluster $1, \mathrm{H} 3 \mathrm{~g}$ & nucleosome assembly & 4.428 & 6.1402062 \\
\hline 206110_at & HIST1H3H & histone cluster $1, \mathrm{H} 3 \mathrm{~h}$ & nucleosome assembly & 11.196 & 4.6453523 \\
\hline 214290_s_at & $\begin{array}{l}\text { HIST2H2AA3 / } \\
\text { HIST2H2AA4 }\end{array}$ & $\begin{array}{l}\text { histone cluster 2, H2aa3 / } \\
\text { histone cluster } 2, \mathrm{H} 2 \mathrm{aa} 4\end{array}$ & nucleosome assembly & 7.84 & 2.5602309 \\
\hline 218280_x_at & $\begin{array}{l}\text { HIST2H2AA3 / } \\
\text { HIST2H2AA4 }\end{array}$ & $\begin{array}{l}\text { histone cluster } 2, \mathrm{H} 2 \mathrm{aa} 3 \text { / } \\
\text { histone cluster } 2, \mathrm{H} 2 \mathrm{aa} 4\end{array}$ & nucleosome assembly & 8.251 & 3.2712434 \\
\hline 201464_x_at & JUN & jun oncogene & $\begin{array}{l}\text { regulation of progression } \\
\text { through cell cycle }\end{array}$ & 3.027 & 3.3020167 \\
\hline 203751_x_at & JUND & jun D proto-oncogene & regulation of transcription & 4.487 & 3.6338656 \\
\hline 203752_s_at & JUND & jun D proto-oncogene & regulation of transcription & 13.193 & 2.5481349 \\
\hline 221841_s_at & KLF4 & Kruppel-like factor 4 (gut) & regulation of transcription & 7.638 & 4.8784029 \\
\hline 201669_s_at & MARCKS & $\begin{array}{l}\text { myristoylated alanine-rich } \\
\text { protein kinase } C \text { substrate }\end{array}$ & cell motility & 6.717 & 3.6042097 \\
\hline 37028_at & PPP1R15A & $\begin{array}{l}\text { protein phosphatase } 1 \text {, } \\
\text { regulatory (inhibitor) } \\
\text { subunit } 15 \mathrm{~A}\end{array}$ & apoptosis & 7.837 & 3.945816 \\
\hline 202988_s_at & RGS1 & $\begin{array}{l}\text { regulator of G-protein } \\
\text { signalling } 1\end{array}$ & signal transduction & 4.321 & 5.0074513 \\
\hline 216834_at & RGS1 & $\begin{array}{l}\text { regulator of G-protein } \\
\text { signalling } 1\end{array}$ & signal transduction & 3.36 & 2.4548041 \\
\hline 202388_at & RGS2 & $\begin{array}{l}\text { regulator of G-protein } \\
\text { signalling } 2,24 \mathrm{kDa}\end{array}$ & cell cycle & 6.536 & 3.0752566 \\
\hline
\end{tabular}




\begin{tabular}{|c|c|c|c|c|c|}
\hline 203455_s_at & SAT1 & $\begin{array}{l}\text { spermidine/spermine N1- } \\
\text { acetyltransferase } 1\end{array}$ & metabolic process & 6.718 & 5.1566265 \\
\hline 210592_s_at & SAT1 & $\begin{array}{l}\text { spermidine/spermine N1- } \\
\text { acetyltransferase } 1\end{array}$ & metabolic process & 10.694 & 5.9428571 \\
\hline 213988_s_at & SAT1 & $\begin{array}{l}\text { spermidine/spermine N1- } \\
\text { acetyltransferase } 1\end{array}$ & metabolic process & 16.284 & 20.706522 \\
\hline 201471_s_at & SQSTM1 & sequestosome 1 & $\begin{array}{l}\text { ubiquitin-dependent protein } \\
\text { catabolic process; apoptosis }\end{array}$ & 7.247 & 2.3460443 \\
\hline 213112_s_at & SQSTM1 & sequestosome 1 & $\begin{array}{l}\text { ubiquitin-dependent protein } \\
\text { catabolic process; apoptosis }\end{array}$ & 9.227 & 3.2893626 \\
\hline 209197_at & SYT11 & synaptotagmin XI & transport & 9.059 & 3.9906351 \\
\hline
\end{tabular}


Table 3b Fifty-nine down-regulated probes in KMS11 upon 24h RPI-1-treatment, ordered by gene name.

\begin{tabular}{|c|c|c|c|c|c|}
\hline Probe ID & GENE & NAME & Biological Process & Zscore & FC \\
\hline 214687_x_at & ALDOA & aldolase A, fructose-bisphosphate & metabolic process & -12.88 & -2.0994035 \\
\hline 201101_s_at & BCLAF1 & $\begin{array}{l}\text { BCL2-associated transcription } \\
\text { factor } 1\end{array}$ & regulation of transcription & -4.548 & -3.9077748 \\
\hline 205780_at & $\mathrm{BIK}$ & $\begin{array}{l}\text { BCL2-interacting killer } \\
\text { (apoptosis-inducing) }\end{array}$ & induction of apoptosis & -13.631 & -13.623077 \\
\hline 217809_at & BZW2 & $\begin{array}{l}\text { basic leucine zipper and W2 } \\
\text { domains } 2\end{array}$ & $\begin{array}{l}\text { regulation of translational } \\
\text { initiation }\end{array}$ & -16.114 & -3.055681 \\
\hline 221777_at & C12orf52 & $\begin{array}{l}\text { chromosome } 12 \text { open reading } \\
\text { frame } 52\end{array}$ & --- & -4.938 & -6.7686275 \\
\hline 204695_at & $\mathrm{CDC} 25 \mathrm{~A}$ & $\begin{array}{l}\text { cell division cycle } 25 \text { homolog A } \\
\text { (S. pombe) }\end{array}$ & $\begin{array}{l}\text { regulation of progression } \\
\text { through cell cycle }\end{array}$ & -2.973 & -4.7608696 \\
\hline 206533_at & CHRNA5 & $\begin{array}{l}\text { cholinergic receptor, nicotinic, } \\
\text { alpha } 5\end{array}$ & transport & -25.569 & -3.5083144 \\
\hline 206185_at & CRYBB1 & crystallin, beta B1 & visual perception & -8 & -11.345345 \\
\hline 202937_x_at & CTA-126B4.3 & CGI-96 protein & --- & -2.536 & -3.9650986 \\
\hline 219328_at & DDX31 & $\begin{array}{l}\text { DEAD (Asp-Glu-Ala-Asp) box } \\
\text { polypeptide } 31\end{array}$ & - & -2.402 & -4.0957746 \\
\hline 201478_s_at & $\mathrm{DKC1}$ & $\begin{array}{l}\text { dyskeratosis congenita } 1, \\
\text { dyskerin }\end{array}$ & $\begin{array}{l}\text { regulation of progression } \\
\text { through cell cycle }\end{array}$ & -7.49 & -3.6414863 \\
\hline 216212_s_at & $\mathrm{DKC1}$ & $\begin{array}{l}\text { dyskeratosis congenita } 1 \text {, } \\
\text { dyskerin }\end{array}$ & $\begin{array}{l}\text { regulation of progression } \\
\text { through cell cycle }\end{array}$ & -3.6 & -6.8414443 \\
\hline 200647_x_at & EIF3S8 & $\begin{array}{l}\text { eukaryotic translation initiation } \\
\text { factor } 3 \text {, subunit } 8,110 \mathrm{kDa}\end{array}$ & translational initiation & -6.229 & -2.810933 \\
\hline 211787_s_at & EIF4A1 & $\begin{array}{l}\text { eukaryotic translation initiation } \\
\text { factor } 4 \mathrm{~A} \text {, isoform } 1\end{array}$ & translation & -11.09 & -2.5325046 \\
\hline 218695_at & EXOSC4 & exosome component 4 & RNA processing & -2.599 & -3.8507653 \\
\hline 202345_s_at & FABP5 / & $\begin{array}{l}\text { fatty acid binding protein } 5 \\
\text { (psoriasis-associated) }\end{array}$ & lipid metabolic process & -10.141 & -4.9094409 \\
\hline 204380_s_at & FGFR3 & $\begin{array}{l}\text { fibroblast growth factor receptor } \\
3\end{array}$ & $\begin{array}{l}\text { MAPKKK cascade; skeletal } \\
\text { development }\end{array}$ & -14.746 & -4.1766544 \\
\hline 219271_at & GALNT14 & $\begin{array}{l}\text { UDP-N-acetyl-alpha-D- } \\
\text { galactosamine:polypeptide N- } \\
\text { acetylgalactosaminyltransferase } \\
14 \text { (GalNAc-T14) }\end{array}$ & --- & -4.676 & -9.4342857 \\
\hline 208308_s_at & GPI & glucose phosphate isomerase & $\begin{array}{l}\text { carbohydrate metabolic } \\
\text { process }\end{array}$ & -13.454 & -2.3725146 \\
\hline 200598_s_at & HSP90B1 & $\begin{array}{l}\text { heat shock protein } 90 \mathrm{kDa} \text { beta } \\
\text { (Grp94), member } 1\end{array}$ & protein folding & -8.318 & -2.9437294 \\
\hline 216449_x_at & HSP90B1 & $\begin{array}{l}\text { heat shock protein } 90 \mathrm{kDa} \text { beta } \\
\text { (Grp94), member } 1\end{array}$ & protein folding & -3.614 & -5.6564311 \\
\hline 208687_x_at & HSPA8 & heat shock $70 \mathrm{kDa}$ protein 8 & protein folding & -9.192 & -2.1817546 \\
\hline 210338_s_at & HSPA 8 & heat shock $70 \mathrm{kDa}$ protein 8 & protein folding & -6.38 & -2.3531494 \\
\hline 200806_s_at & HSPD1 & $\begin{array}{l}\text { heat shock } 60 \mathrm{kDa} \text { protein } 1 \\
\text { (chaperonin) }\end{array}$ & protein folding & -13.021 & -2.6769356 \\
\hline 205133_s_at & HSPE1 & $\begin{array}{l}\text { heat shock } 10 \mathrm{kDa} \text { protein } 1 \\
\text { (chaperonin } 10 \text { ) }\end{array}$ & protein folding & -5.967 & -2.9735466 \\
\hline
\end{tabular}




\begin{tabular}{|c|c|c|c|c|c|}
\hline 204744_s_at & IARS & isoleucyl-tRNA synthetase & translation & -13.347 & -2.2747016 \\
\hline 205902_at & KCNN3 & $\begin{array}{l}\text { potassium intermediate/small } \\
\text { conductance calcium-activated } \\
\text { channel, subfamily } \mathrm{N} \text {, member } 3\end{array}$ & transport & -38.442 & -11.700565 \\
\hline 212396_s_at & KIAA0090 & KIAA0090 & & -5.361 & -4.0614925 \\
\hline 210153_s_at & ME2 & $\begin{array}{l}\text { malic enzyme 2, NAD(+)- } \\
\text { dependent, mitochondrial }\end{array}$ & malate metabolic process & -9.247 & -3.0939496 \\
\hline 218664_at & MECR & $\begin{array}{l}\text { mitochondrial trans-2-enoyl-CoA } \\
\text { reductase }\end{array}$ & fatty acid metabolic process & -4.1 & -4.4507227 \\
\hline 221286_s_at & MGC29506 & hypothetical protein MGC29506 & --- & -16.293 & -4.7685857 \\
\hline 202431_s_at & MYC & $\begin{array}{l}\text { v-myc myelocytomatosis viral } \\
\text { oncogene homolog (avian) }\end{array}$ & regulation of cell proliferation & -9.337 & -3.8867842 \\
\hline 222206_s_at & NCLN & nicalin homolog (zebrafish) & protein processing & -48.216 & -16.824324 \\
\hline 209062_x_at & NCOA3 & nuclear receptor coactivator 3 & regulation of transcription & -6.077 & -5.0058366 \\
\hline 201577_at & NME1 & $\begin{array}{l}\text { non-metastatic cells } 1 \text {, protein } \\
\text { (NM23A) expressed in }\end{array}$ & $\begin{array}{l}\text { GTP biosynthetic process; } \\
\text { regulation of apoptosis }\end{array}$ & -11.056 & -2.7143663 \\
\hline 221923_s_at & NPM1 & $\begin{array}{l}\text { nucleophosmin (nucleolar } \\
\text { phosphoprotein B23, numatrin) }\end{array}$ & $\begin{array}{l}\text { intracellular protein transport } \\
\text { centrosome cycle }\end{array}$ & -16.131 & -2.8534306 \\
\hline 201013_s_at & PAICS & $\begin{array}{l}\text { phosphoribosylaminoimidazole } \\
\text { carboxylase, } \\
\text { phosphoribosylaminoimidazole } \\
\text { succinocarboxamide synthetase }\end{array}$ & $\begin{array}{l}\text { purine nucleotide biosynthetic } \\
\text { process }\end{array}$ & -13.995 & -2.7359484 \\
\hline 201014_s_at & PAICS & $\begin{array}{l}\text { phosphoribosylaminoimidazole } \\
\text { carboxylase, } \\
\text { phosphoribosylaminoimidazole } \\
\text { succinocarboxamide synthetase }\end{array}$ & $\begin{array}{l}\text { purine nucleotide biosynthetic } \\
\text { process }\end{array}$ & -10.937 & -4.2608932 \\
\hline 201481_s_at & PYGB & phosphorylase, glycogen; brain & $\begin{array}{l}\text { carbohydrate metabolic } \\
\text { process }\end{array}$ & -3.423 & -5.5689046 \\
\hline 213205_s_at & RAD54L2 & RAD54-like 2 (S. cerevisiae) & --- & -6.091 & -4.7007874 \\
\hline 202483_s_at & RANBP1 & RAN binding protein 1 & $\begin{array}{l}\text { spindle organization and } \\
\text { biogenesis }\end{array}$ & -8.356 & -2.800464 \\
\hline 211955_at & RANBP5 & RAN binding protein 5 & protein transport & -7.299 & -3.7969231 \\
\hline 216360_x_at & RRP12 & $\begin{array}{l}\text { ribosomal RNA processing } 12 \\
\text { homolog (S. cerevisiae) }\end{array}$ & & -2.808 & -4.2506297 \\
\hline 216913_s_at & RRP12 & $\begin{array}{l}\text { ribosomal RNA processing } 12 \\
\text { homolog (S. cerevisiae) }\end{array}$ & & -3.143 & -7.419214 \\
\hline 204133_at & RRP9 & $\begin{array}{l}\text { RRP9, small subunit (SSU) } \\
\text { processome component, homolog } \\
\text { (yeast) }\end{array}$ & rRNA processing & -9.295 & -10.423729 \\
\hline 211162_x_at & SCD & $\begin{array}{l}\text { stearoyl-CoA desaturase (delta-9- } \\
\text { desaturase) }\end{array}$ & lipid metabolic process & -6.662 & -15.764516 \\
\hline 211708_s_at & $\mathrm{SCD}$ & $\begin{array}{l}\text { stearoyl-CoA desaturase (delta-9- } \\
\text { desaturase) }\end{array}$ & lipid metabolic process & -7.944 & -5.8237965 \\
\hline 208863_s_at & SFRS1 & $\begin{array}{l}\text { splicing factor, arginine/serine- } \\
\text { rich } 1 \text { (splicing factor } 2 \text {, alternate } \\
\text { splicing factor) }\end{array}$ & mRNA processing & -7.147 & -3.8212545 \\
\hline 200754_x_at & SFRS2 & $\begin{array}{l}\text { splicing factor, arginine/serine- } \\
\text { rich } 2\end{array}$ & mRNA processing & -4.359 & -2.202939 \\
\hline
\end{tabular}




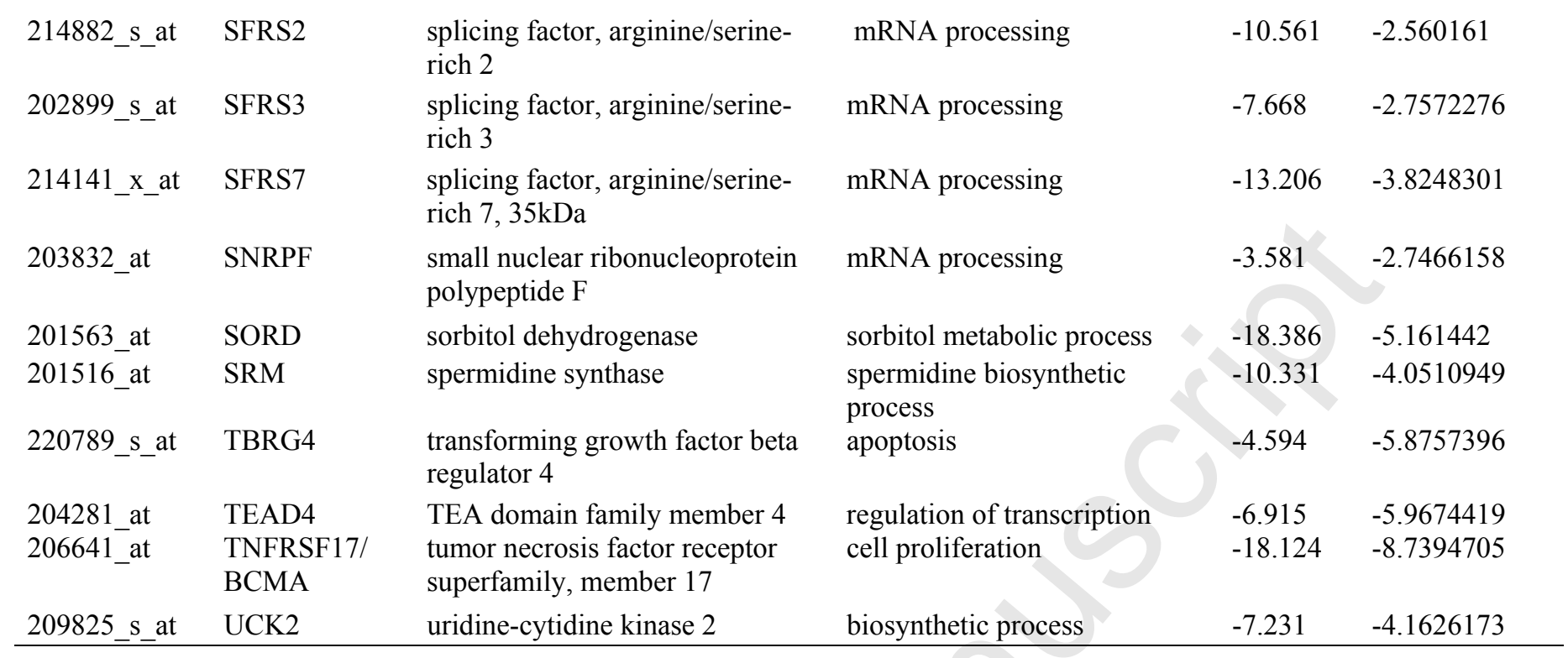


A

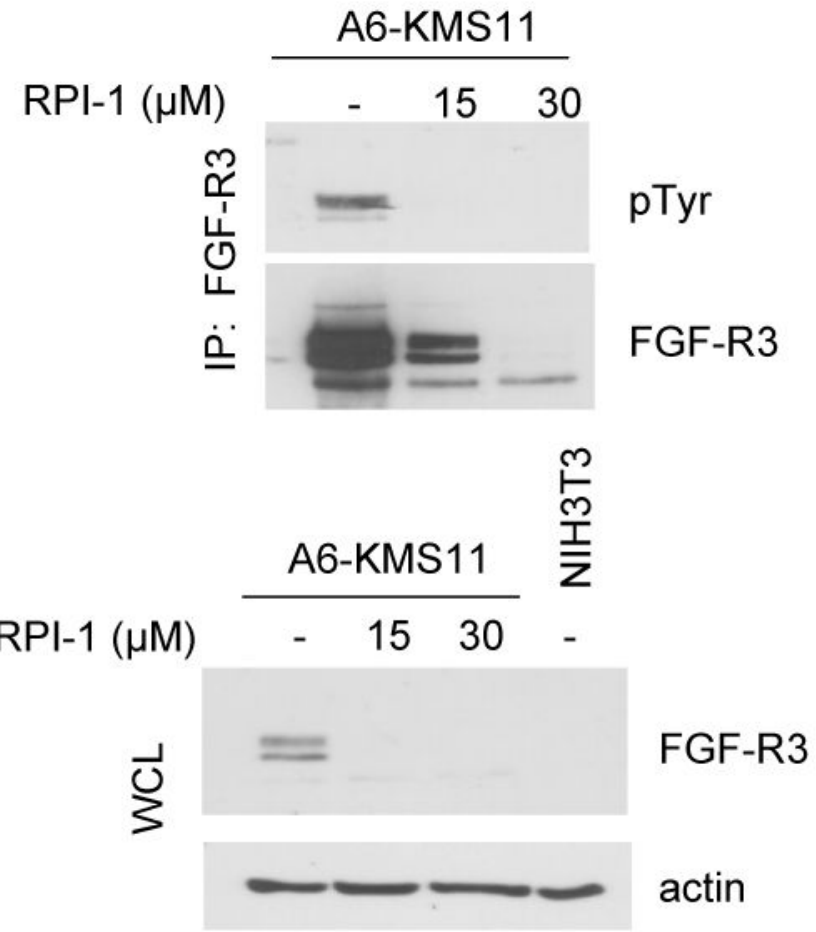

B

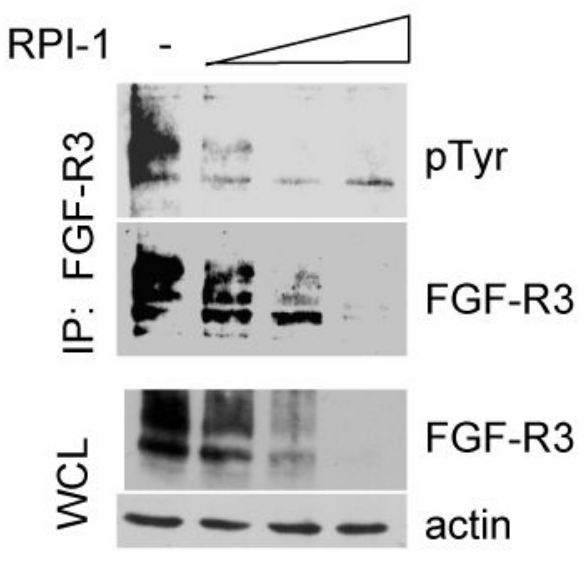

C

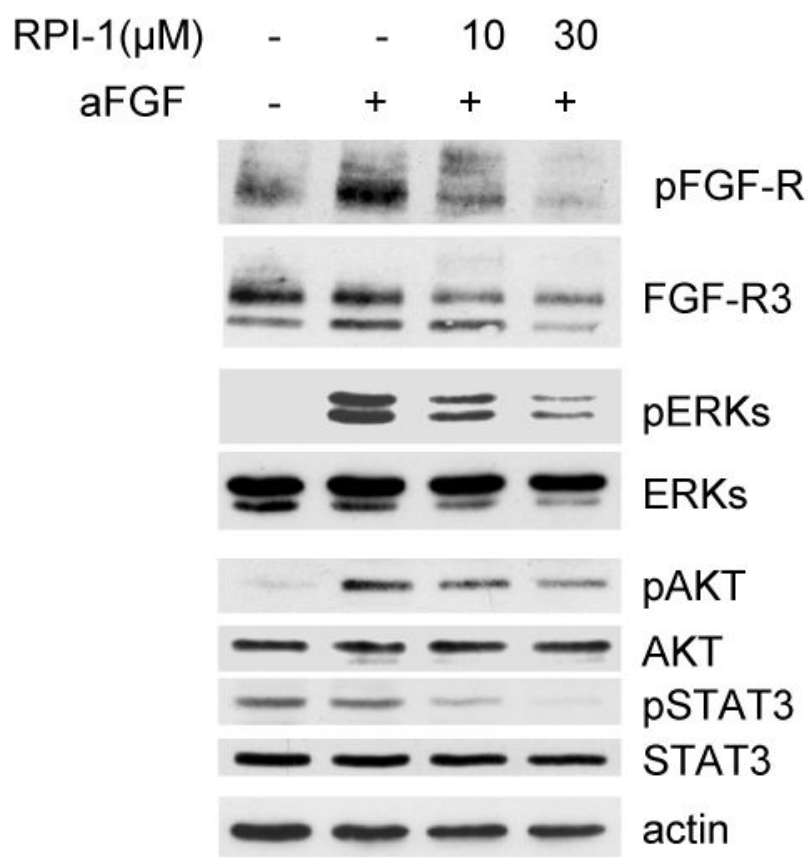

D

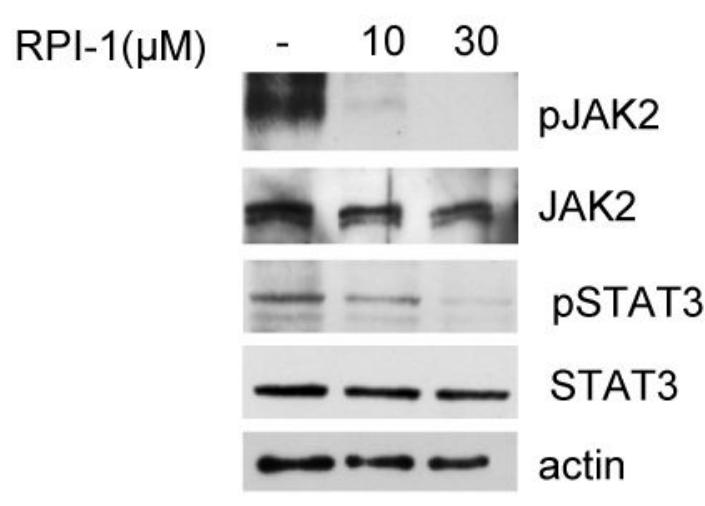


A
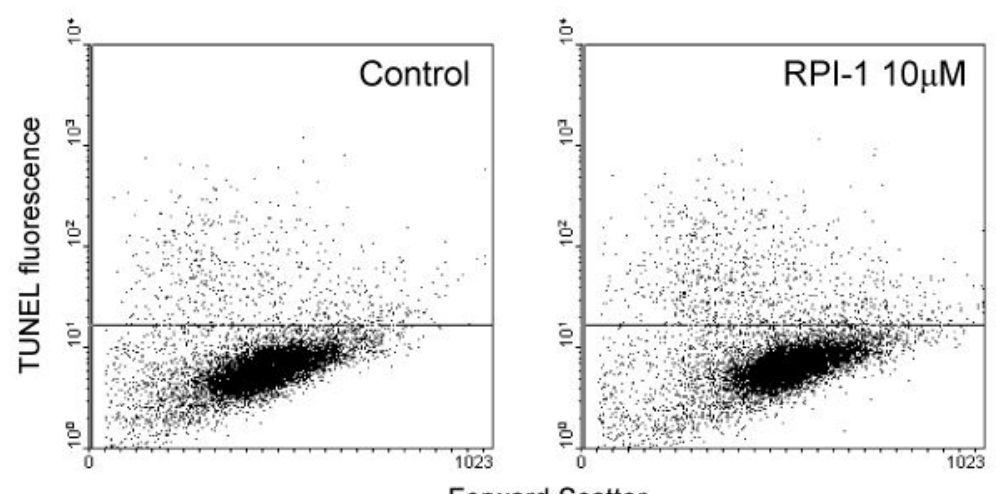

Forward Scatter
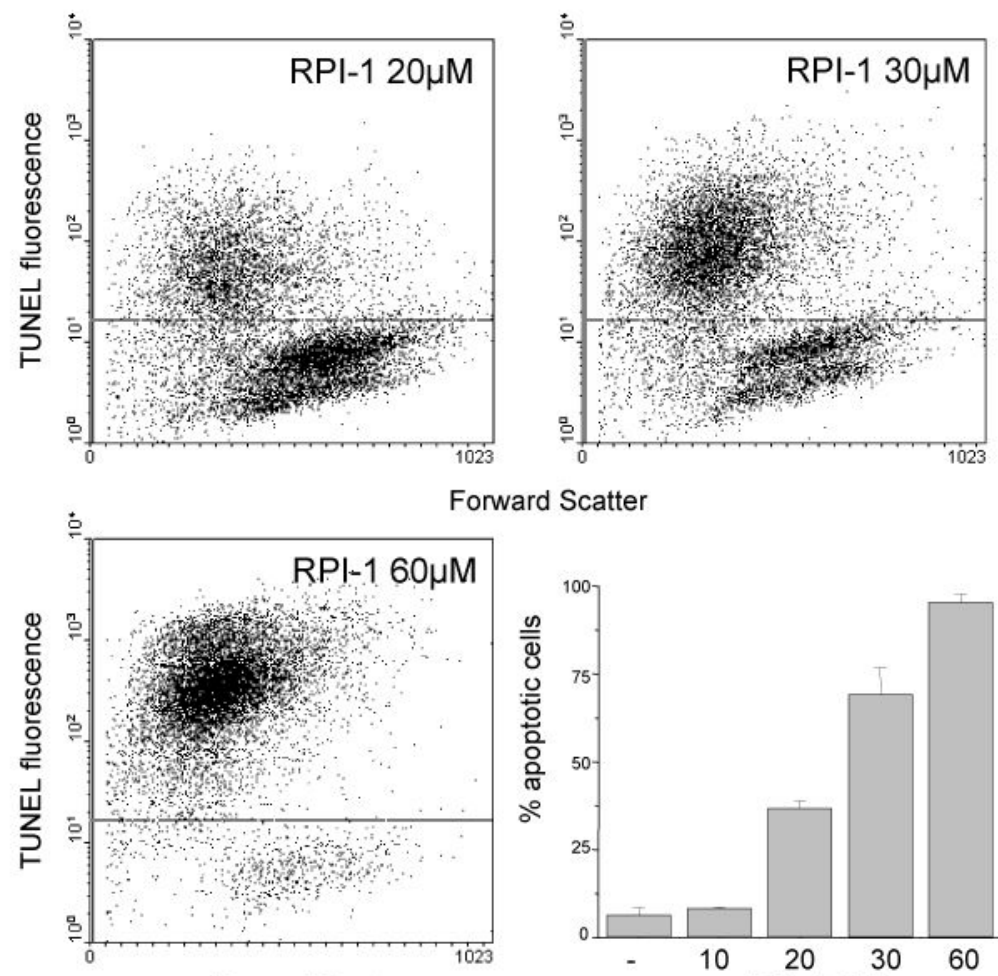

Forward Scatter

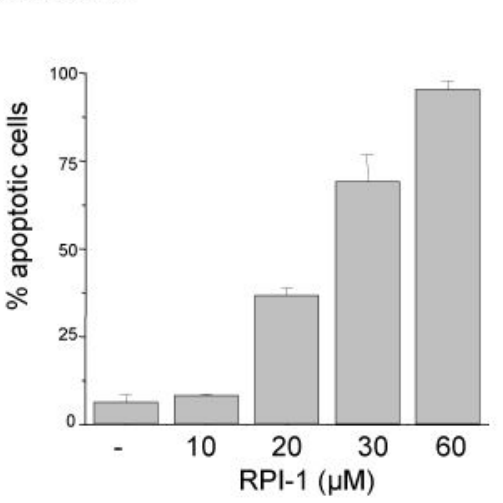

B

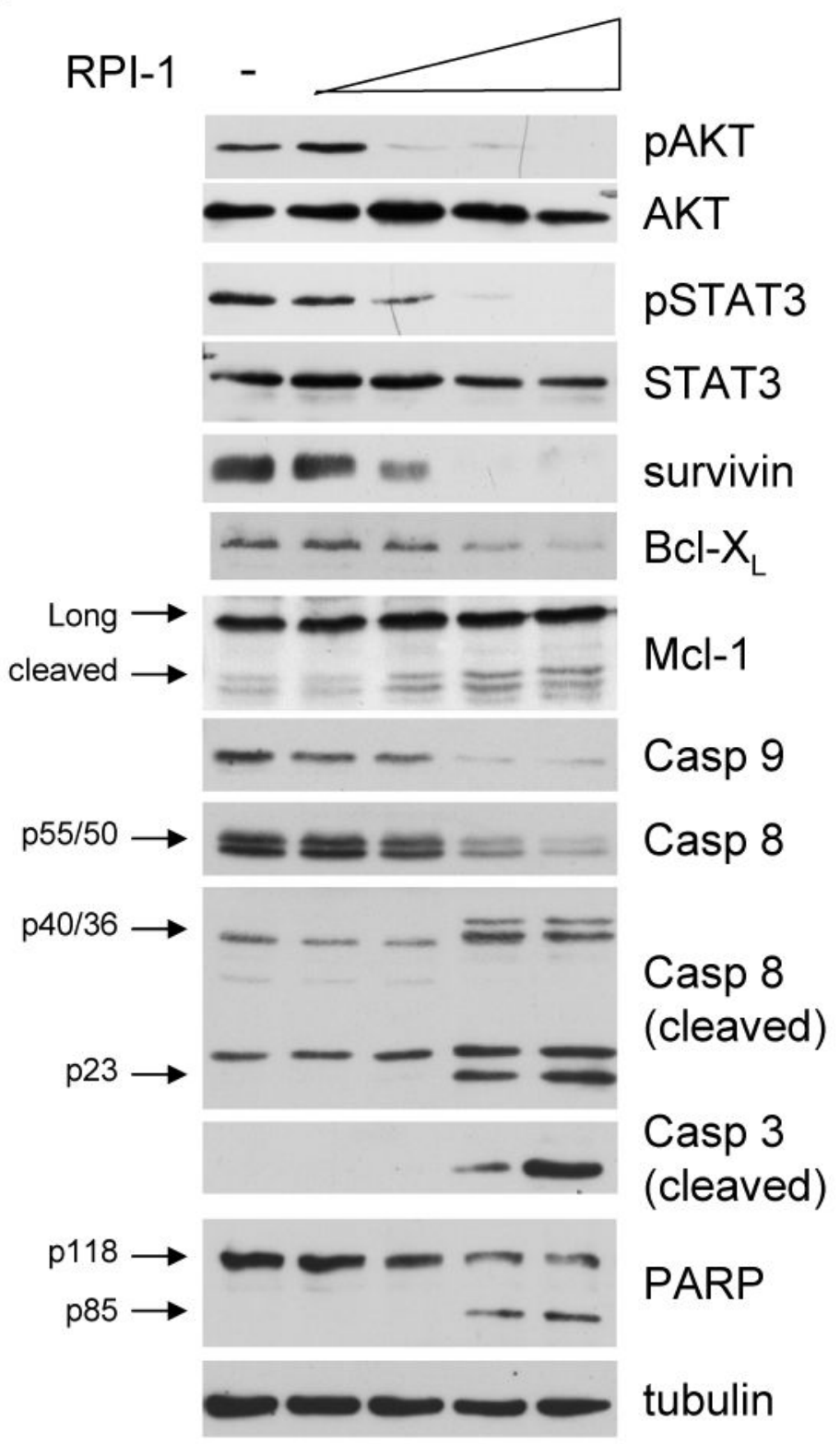

Fig. 3 


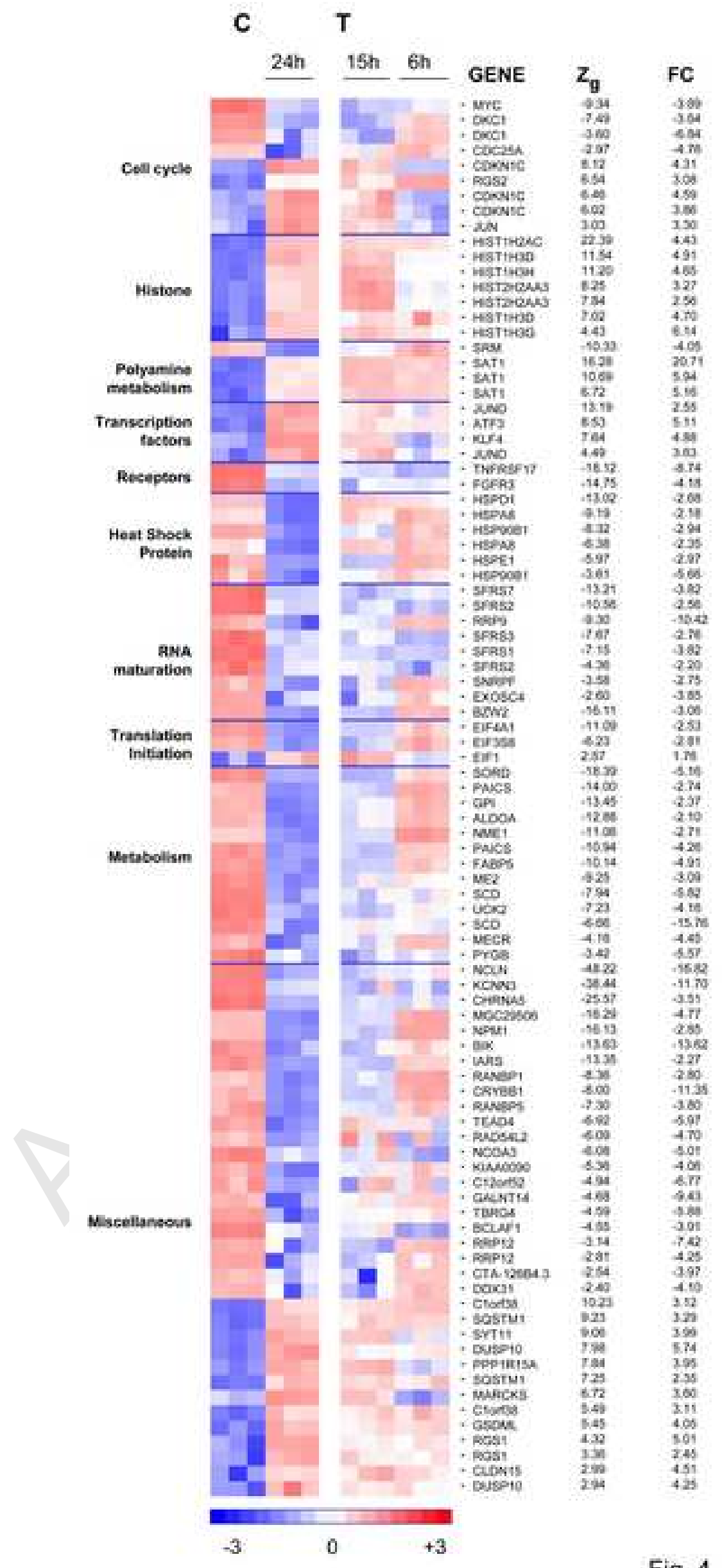

Fig. 4 


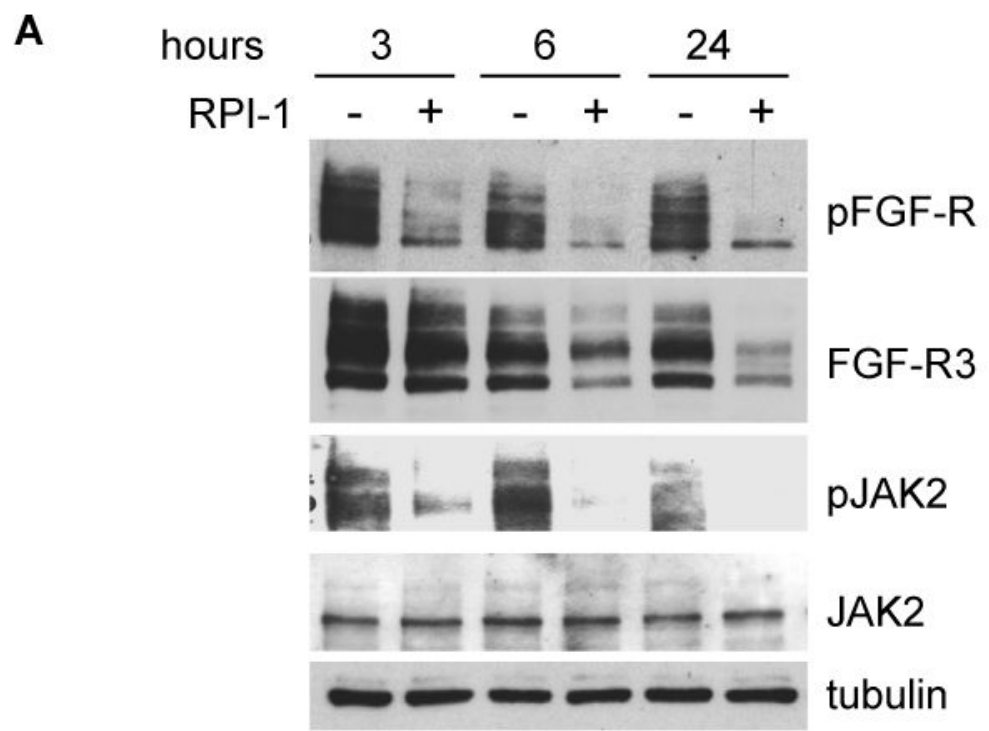

B

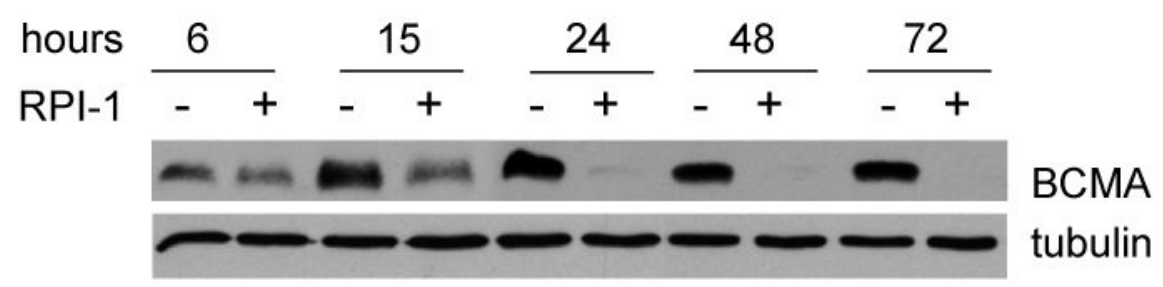

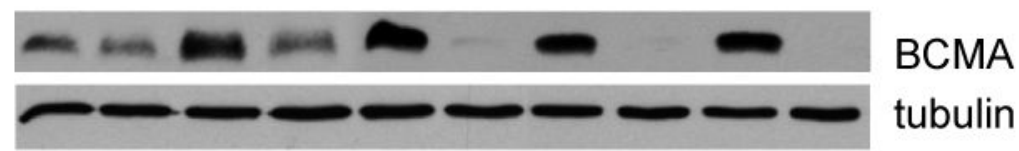

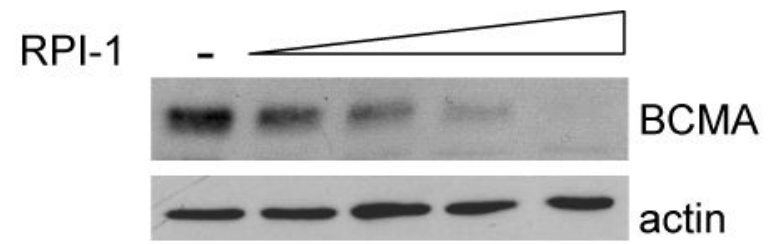

C

$$
\begin{aligned}
\text { hours } \frac{6}{2+} \frac{15}{-+} \frac{24}{-+} \stackrel{48}{-+} \\
\text { RPI-1 } \\
=-\infty=-\infty=0 \text { Myc } \\
\text { tubulin }
\end{aligned}
$$

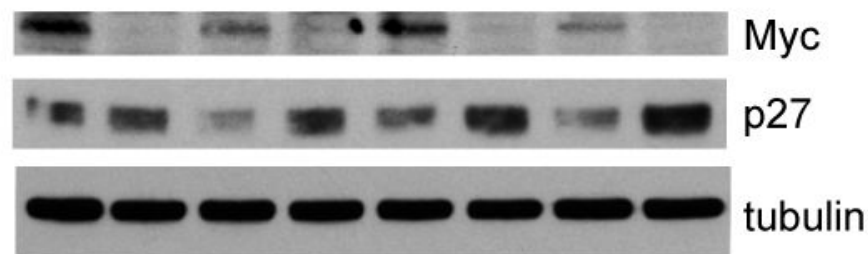

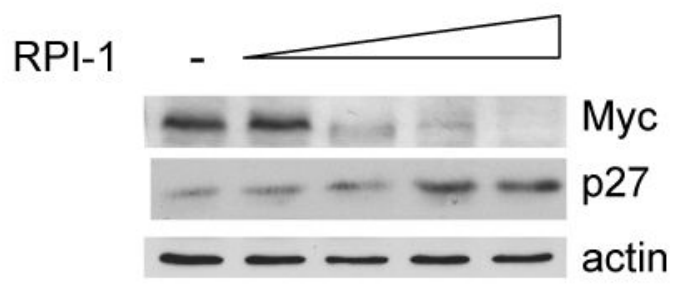

Fig. 5 
A

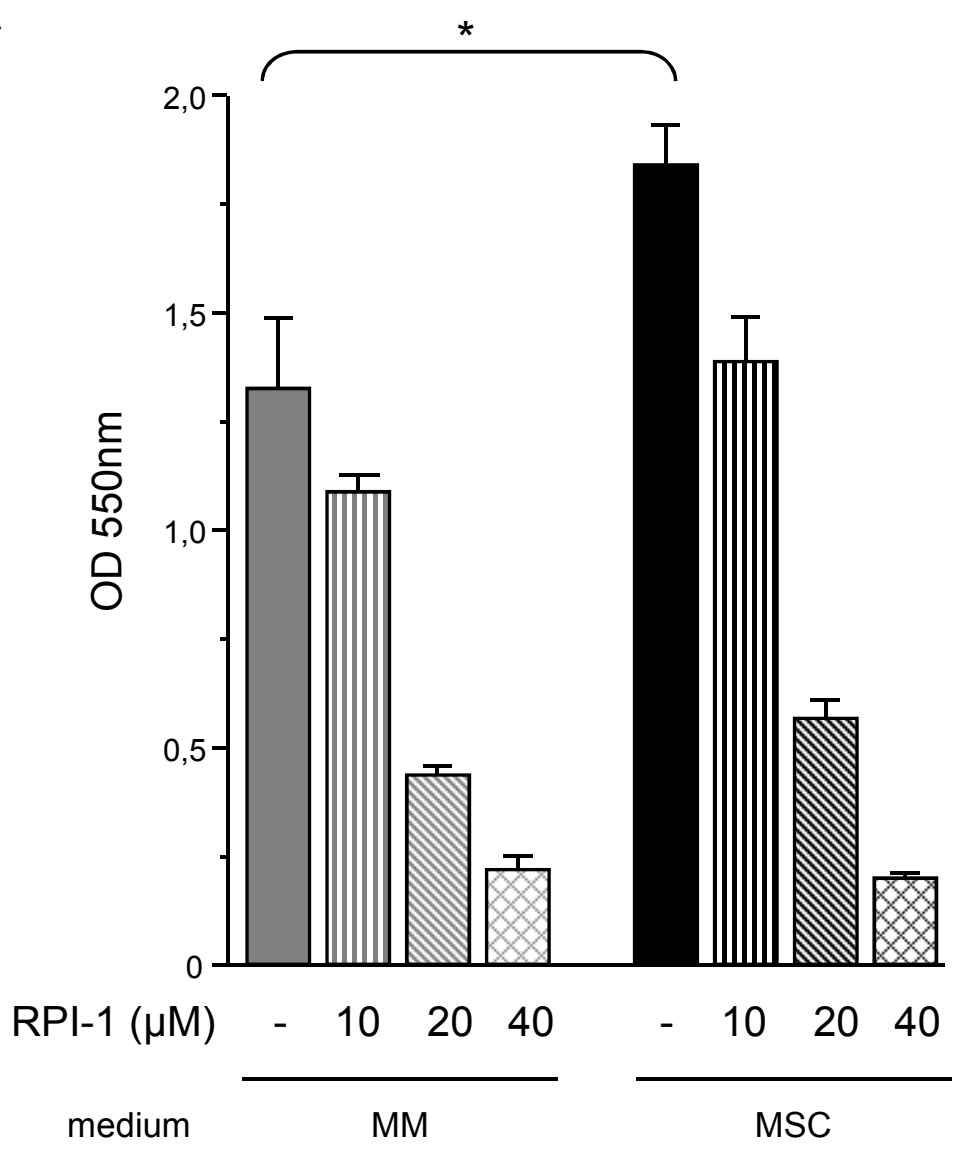

B

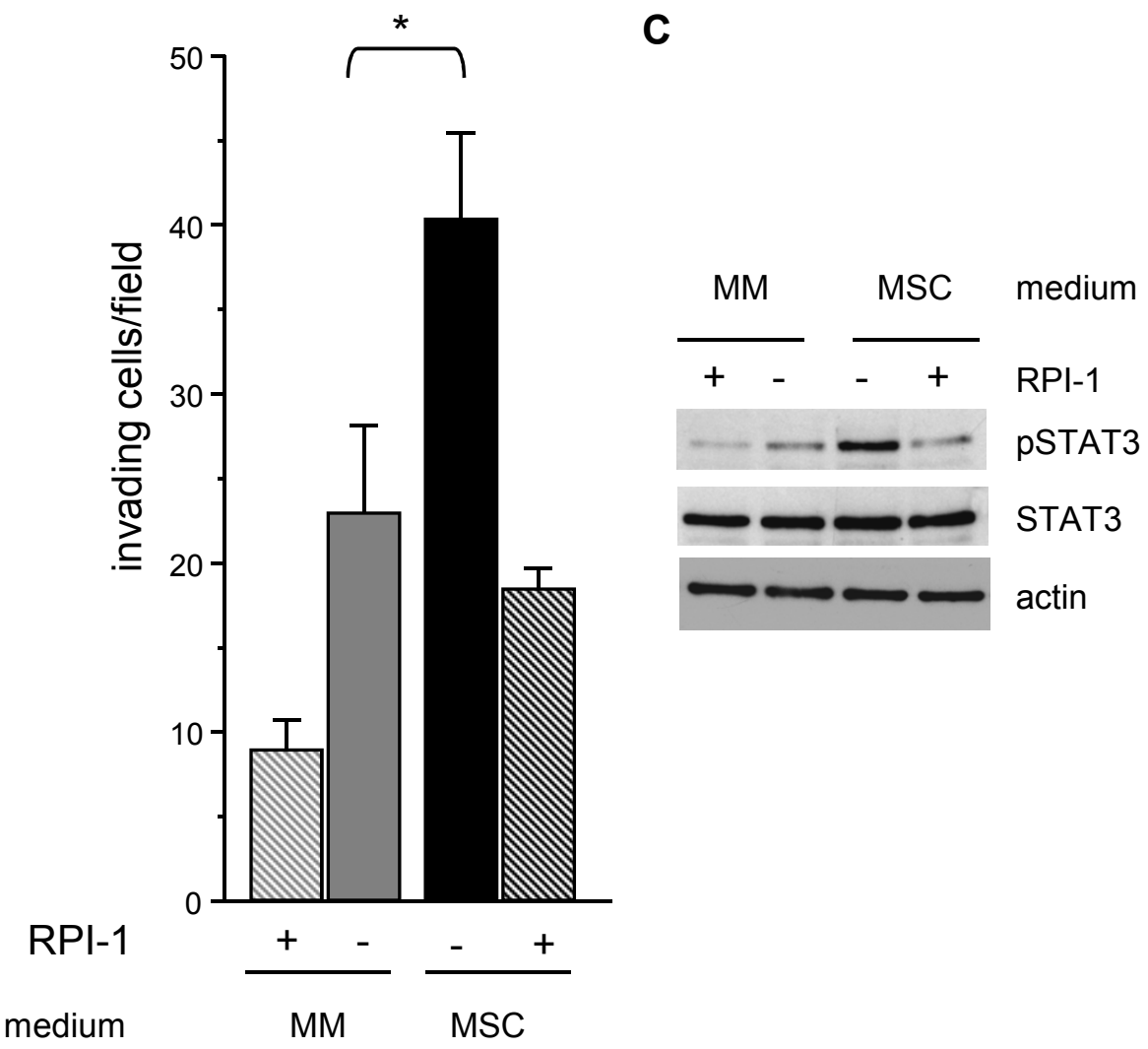

Fig. 6 
Multiple pathways sustaining MM pathobiology are blocked by the multi-target tyrosine kinase inhibitor RPI-1

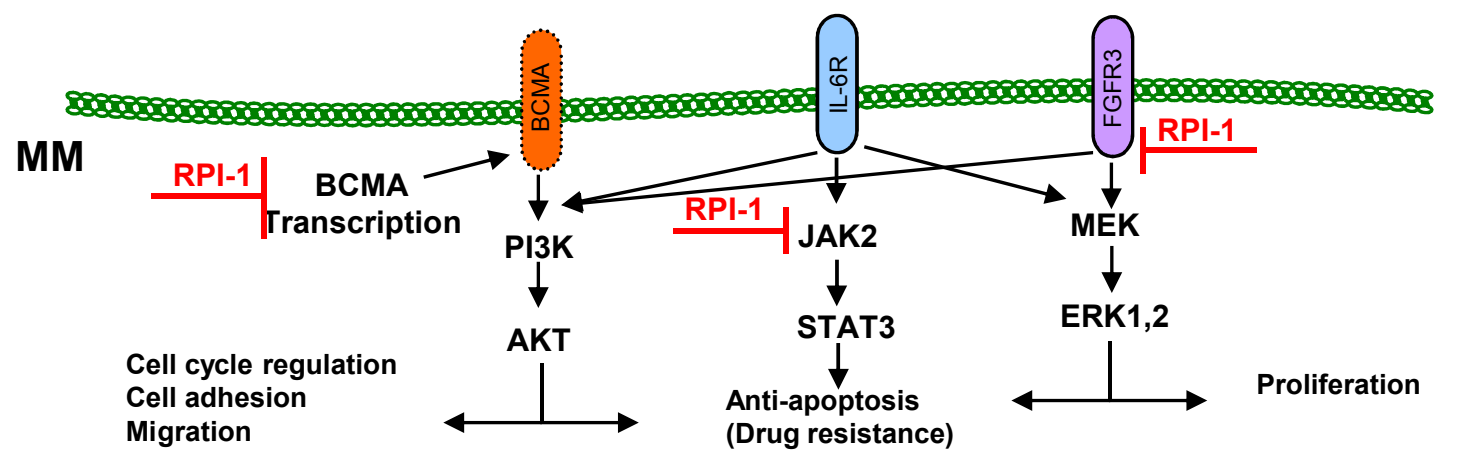

Cassinelli et al. Graphical Abstract 